Portland State University

PDXScholar

Dissertations and Theses

Dissertations and Theses

Spring 7-22-2013

\title{
Truth and Memory in Two Works by Marguerite Duras
}

Rachel Deborah Hunter

Portland State University

Follow this and additional works at: https://pdxscholar.library.pdx.edu/open_access_etds

Part of the European History Commons, French and Francophone Literature Commons, Jewish Studies Commons, and the Military History Commons

Let us know how access to this document benefits you.

\section{Recommended Citation}

Hunter, Rachel Deborah, "Truth and Memory in Two Works by Marguerite Duras" (2013). Dissertations and Theses. Paper 1008.

https://doi.org/10.15760/etd.1008

This Thesis is brought to you for free and open access. It has been accepted for inclusion in Dissertations and Theses by an authorized administrator of PDXScholar. Please contact us if we can make this document more accessible: pdxscholar@pdx.edu. 
Truth and Memory in Two Works by Marguerite Duras

\title{
by
}

Rachel Deborah Hunter A thesis submitted in partial fulfillment of the
requirements for the degree of

\author{
Master of Arts \\ in \\ French
}

\begin{abstract}
Thesis Committee:
Annabelle Dolidon, Chair

Isabel Jaen Portillo

Stephen Walton
\end{abstract}

Portland State University

2013 
C 2013 Rachel Deborah Hunter 


\begin{abstract}
Published in 1985, Marguerite Duras' La Douleur is a collection of six autobiographical and semi-autobiographical short stories written during and just after the German Occupation. Echoing the French national sentiment of the 1970s and 1980s, these stories examine Duras' own capacity for good and evil, for forgetting, repressing, and remembering. The first of these narratives, the eponymous "La douleur," is the only story in the collection to take the form of a diary, and it is this narrative, along with a posthumously published earlier draft of the same text, that will be the focus of this thesis. In both versions, Duras recounts her last tortuous months of waiting for her husband, Robert Antelme, to return from a German concentration camp after he was arrested and deported for his participation in the French Resistance. Though Duras claims in her 1985 preface to "La douleur" that she has no memory of having written this diary and that it has "nothing to do with literature," when it is compared to the original version it becomes clear that substantial changes in style and tone were made to the 1985 version before publication. Though many of Duras' peers disregarded this rewritten version of "La douleur" as a shameful distortion of the truth, it is my contention that historical accuracy was never Duras' primary goal. Instead, what manifests in these two versions of the same story is Duras' path toward understanding and closure in the wake of a traumatic event. Using a combination of psychoanalytic and post-structuralist theory, I will show that Truth and History are essentially incompatible when narrating trauma. Instead what is central to these two texts is their emotional accuracy: the manner in which the feelings and impressions associated with a traumatic event are accurately portrayed.
\end{abstract}


To Yvonne Messick and Jennifer Lea 


\section{Acknowledgements}

I would first like to express my sincere gratitude to my thesis advisor, Dr. Annabelle Dolidon, whose insight, guidance, and encouragement both challenged and motivated me throughout the writing process. I would also like to extend my thanks to the entire French department at Portland State University for granting me the opportunity to explore and develop my own research interests in such a supportive environment.

I would like to thank Clément Guillaume, whose camaraderie has been indispensable this year. This would have been a lonely endeavor without him. Many thanks as well to my 'extended family' of friends in Portland. Their genuine interest in my studies and this thesis were a continual source of energy and motivation.

A most heartfelt thank you to Ben Woodhouse for his humor, compassion, patience, countless words of encouragement, and psychic hand-squeezes.

Lastly, I would like to thank my family for not only allowing, but encouraging me to follow my heart and pursue my studies in French literature. They have been my biggest cheerleaders - Je vous aime! 
Table of Contents

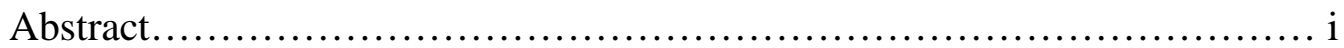

Dedication.......................................................... ii

Acknowledgements.................................................. iii

Introduction

Toward a New Understanding of 'Accuracy'................................................. 1

Chapter I

Remembering Trauma: Recalling the Uncertain........................................ 22

Chapter II

Narrating Trauma: Mastering the Unknown ............................................... 41

Chapter III

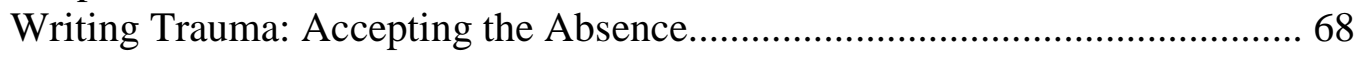

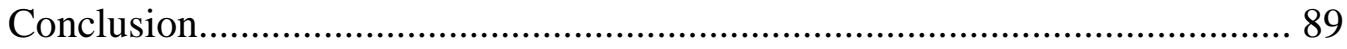

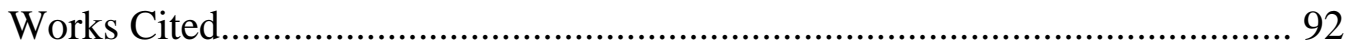




\section{Introduction}

\section{Toward a New Understanding of 'Accuracy'}

When Marguerite Duras' La Douleur was published in 1985, it followed on the heels of what may be considered a national crisis of identity over the events of the Occupation between 1940 and 1944. "Le miroir se brise et les mythes volent en éclats," (19) wrote Henry Rousso, referring to the mythe du résistancialisme promulgated by General De Gaulle after the Liberation (as well as Communists and other political figures seeking to play a role in France's post-war reconstruction), which claimed that France had resisted the Nazis when in fact collaboration had been widespread. A growing interest in the previous generation's war-time experience, the advent of a European community that little by little chipped away at the imperative of nationalist sentiment, and the powerful resurgence of anti-Semitism manifest in the Faurisson and Darquier affairs, ${ }^{1}$ as well as the subsequent proliferation of testimony from those who survived the German camps, made it increasingly difficult to accept the old notion that France had unanimously resisted - even if passively - the German occupation. ${ }^{2}$ Just as Marshal Pétain had sought to "recomposer l'âme national," through the Vichy Regime's ethos of Travail,

\footnotetext{
${ }^{1}$ A professor of literature at the University of Lyon, Robert Faurisson published two letters in the French newspaper Le Monde in 1978 claiming the gas chambers used by the Nazis for the purpose of exterminating Jews never existed. In October of that year, the magazine L'Express published an interview with the former Commissioner for Jewish Affairs under the Vichy Regime, Louis Darquier de Pellepoix. Like Faurisson, Darquier also denied the existence of any Nazi extermination camps and referred to the Final Solution as "une invention pure et simple" (Rousso 164).

${ }^{2}$ For a more complete discussion of the Résistance's influence during post-war reconstruction in France see Henry Rousso's Le syndrome de Vichy.
} 
Famille, Patrie (replacing the Republican Liberté, Egalité, Fraternité), De Gaulle did so too after the end of WWII through the image of La France Résistante (Burrin 334).

Following four years of war, occupation, repression, and suspicion, and the accompanying economic and social hardships, transforming la Résistance into an objet de mémoire that could be uniformly inscribed within a collective histoire-mémoire allowed France to rebuild a national identity unsullied by the specter of a collaborationist regime. But this would be called into question when the new generation of historians, filmmakers, and writers, who were ready to "break the mirror" in which the country sought to affirm its national history and identity, re-examined the archives.

Revisiting these années noires in the 1970s and 1980s and calling into question l'oubli juridique that had allowed for numerous amnesties to be granted to Vichy officials paved the way for a new, previously unexplored discourse: why and how was the Vichy Regime able to come into power? Why and how was the memory of Vichy so ardently repressed? Historian Colin Jones has observed that breaking all ties with Vichy, including putting an end to recrimination, encouraged a "fresh start" for a country in which "no one seemed to have clean hands" (278). Questioning these amnesties, pursuing war criminals such as Klaus Barbie with a renewed vigor, Antenne 2's ${ }^{3}$ agreement to finally air Martin Chomsky's Holocaust - it seemed that the French were perhaps ready to reexamine the depth of their involvement with their former Nazi oppressors.

Following this nationwide inclination toward repression, revision, and acceptance, Marguerite Duras published La Douleur, a collection of six short stories that she wrote

\footnotetext{
${ }^{3}$ Antenne 2, now called France 2, is a French national public television channel.
} 
during and shortly after the period of German Occupation. As though anticipating the national sentiment to come, Duras writes ironically in the first of these stories, "La seule réponse à faire à ce crime est d'en faire un crime de tous. De le partager" (65). In these six narratives Duras explores her own capacity for good and evil, her own ability to look at the past objectively, and her own attempt to select from her fractured memories and build from them a cohesive, coherent narrative that accurately represents this era of her life as she experienced it. Duras' written testimony bears witness to her own previously repressed traumatic past, examining the conditions under which one is able to bring to an end the suffering and mourning associated with trauma, and adopting a unique approach to the push and pull between facts and emotions - the paradox of memory.

Unlike previous autobiographical or semi-autobiographical narratives by Duras, such as Un barrage contre le pacifique (1950) or L'amant (1984), La Douleur distinguishes itself through its blending of autobiographical and explicitly fictional narratives. The first four narratives, "La douleur," "Monsieur X., dit ici Pierre Rabier," "Albert des capitales," and "Ter le milicien," are intended to be read as autobiographical accounts of Duras' wartime experience. Each begins with a preface, presumably written shortly before publication in 1985, in which Duras states that these are true stories, that she is present in them $(12,90,138)$. The last two narratives, "L'ortie brisée" and "Aurélia Paris," are fictional, denoted by Duras' "C'est inventé. C'est de la littérature” (194). Yet the only narrative in this collection that appears in the form of a diary is the first one: the eponymous "La douleur." In the present study I will focus on this narrative, as well as an earlier draft of the same text found in Duras' personal notebooks and later included in 
Cahiers de la Guerre et Autres Textes, ${ }^{4}$ a collection of drafts and sketches from Duras' personal archives. Central to these two separate accounts of the same events (separated by 40 years) is a clear juxtaposition of Duras' desire to objectively recall the past and the human compulsion to forget.

"La douleur" begins in April 1945 and chronicles Duras' last tortuous month of waiting for her husband, Robert Antelme, (renamed Robert L. for the 1985 rewritten version, perhaps in reference to his war-time alias, Robert Leroy) to return from a German prison camp. Antelme and Duras, as well as Dionys Mascolo (Antelme's friend and Duras' lover) all belonged to the Mouvement National des Prisonniers de Guerre et Deportés (MNPGD), a Résistance group led by future president of France François Mitterrand. Antelme, along with his sister Marie-Louise and two other members of the group were arrested in June 1944; Antelme was sent to Buchenwald. By April 1945 France had been free from Nazi rule for eight months and the German surrender loomed large. However, the status of all those whom the Nazis had deported remained uncertain, and it is this uncertainty and the utter anguish it caused that is fastidiously rendered by Duras in her diary. In it, Duras teeters on the brink of madness, certain at one moment that her husband will return, convinced he has been dead for weeks the next. Robert is eventually discovered by Mitterrand at Dachau in a state near death and transported home by Mascolo and Georges Beauchamp, but until he returns home, and even while he is recovering, Duras cannot eat, cannot sleep, and cannot hold her head up. Some entries in

\footnotetext{
${ }^{4}$ Cahiers de la Guerre comprises four of Duras' personal notebooks, two of which contain the original version of "La douleur."
} 
the diary bear a precise date; others are only dated "avril"; others give no date at all, echoing Cathy Caruth's assertion in Unclaimed Experience that the overwhelming incomprehensibility of trauma prompts a break in the mind's experience of time (61).

In addition to the inconsistency of dates, the original and rewritten diary exhibit other idiosyncrasies that cast doubt on the temporal positioning of the narrating Duras and the author Duras. I feel a distinction must be made here between the Duras who speaks from within the story - what Gérard Genette refers to as histoire, the narrative contents - and the Duras who authors the narrative - récit, or the narrative text itself (Genette 27). The individuality of these two distinct selves is repeatedly implied within both the story and the narrative text, a point which I will discuss in more detail as I explore the processes of remembering, narrating, and writing. "La douleur" (the rewritten version of the diary published in 1985) contains references to future events that the narrating Duras could not possibly have foreseen in 1945, such as Antelme's memoir L'espèce humaine which would not be published until 1947 (La Douleur 82), and the death of a neighbor's daughter which she would learn of in November 1945 (58). Further complicating matters is the way in which the narrating Duras alternates between the pronouns 'je' and 'elle' to refer to herself at pivotal moments in the narrative. These peculiarities, whether or not created deliberately by Duras, have subsequently generated much debate among critics such as Leslie Hill and Gabriel Jacobs regarding the rewritten diary's accuracy, a sentiment echoed by former peers of Duras, including Mascolo and Mitterrand, who chided Duras after the collection of stories in La Douleur was published for her unabashed misrepresentation of events as they actually occurred. Fellow résistants 
Henri Frenay and Jacques Benet requested that corrections be made to future editions, noting the enormity of her fantasies, "the falsehood of this huge blunder exploited as though it were a historic truth to gratify the public's baser instincts" (Adler 354).

Mitterrand confirmed: "La Douleur is not the most scrupulous of her books" (354).

In “Spectres of Remorse: Duras' War-Time Autobiography," Gabriel Jacobs notes that the blurring of fact and fiction in La Douleur undermines any element of selfanalysis in the text. Jacobs bases this assertion on Duras' own admission in an interview with author Marie-Pierre Fernandes to reworking the text before its publication (48), as well as the numerous minor differences that occur between the "La douleur" of 1985 and the extracts from this second version that were published anonymously in 1976 under the title "Pas mort en déportation" in the feminist literary review Sorcières. ${ }^{5}$ By 1985, Duras was well known for revisiting the same places in her work, with the same people, the same scenes. The "La douleur" published in 1985, for all its proclaimed accuracy, was equally susceptible to reformulation. Yet Duras states rather surprisingly in her 1985 preface to "La douleur" that though she has no memory of writing this previously forgotten and now rediscovered diary, there is no question in her mind regarding its authenticity and veracity, writing: “Je sais que je l'ai fait, que c'est moi qui l'ai écrit, je reconnais mon écriture et le détail de ce que je raconte, je revois l'endroit, la gare

5 "Pas mort en déportation" did not appear in print again until 2006, when Cahiers de la Guerre et Autres Textes was published. Though it was incorporated into the ending of the "La douleur" of 1985, in Cahiers de la Guerre it appears separately from the first version of "La douleur" and is contained within a separate notebook. The majority of what would become the rewritten version of "La douleur" is found at the end of the second notebook, the "Cahier Presses du XXe Siècle," and beginning of the third, the "Cahier de Cent Pages." "Pas mort en deportation" appears in the last notebook, the "Cahier Beige." 
d'Orsay, les trajets, mais je ne me vois pas écrivant ce Journal" (12). She does not acknowledge the previous anonymously published excerpts from 1976, makes no mention of its rewriting, and does not specify when it was that she rediscovered the diary. ${ }^{6}$ Yet with the publication of Cahiers de la Guerre ten years after Duras' death, the original, raw version of "La douleur" is now available; reading this first version as a contemporary account of the events it describes shows that Duras did indeed edit the diary before publishing it in 1985. While the events described within each version remain the same, the "La douleur" of 1985 depicts a narrating self who herself is extraordinarily calm in comparison to her earlier textual self. It would seem that with the passage of time Duras' narrative voice evolves, first speaking in the wake of a traumatic experience, and then from an intellectualized memory of the past imposed in the present.

It is unknown whether Duras ever intended for this first, raw version of "La douleur" to be published, but it is not unthinkable that she saw it as a possibility when she left her personal archives to L'Institut Mémoires de l'Édition Ccontemporaine (IMEC) ${ }^{7}$ in 1995, just one year before her death. Nevertheless, in the preface to "La douleur," Duras avoids any allusion to the existence of a first or different version. She claims that she cannot remember writing the diary, adding that she forgot it even existed until Sorcières asked her for "un texte de jeunesse" (12). As readers, we are meant to believe that Duras wrote the diary between April 1945 and the spring of 1946, stowed it away in

${ }^{6}$ For the purpose of this paper I will not focus on 'Pas mort en déportation' as a third and separate text. Though separate from the original diary, this short story would later be incorporated into the "La douleur" published in 1985.

${ }^{7}$ Created in 1988, L'Institut Mémoires de l'Édition Contemporaine is a private organization devoted to the preservation of literary archives. 
her home in Neauphle-le-Château, just east of Paris, and forgot all about it. This act seems as astonishing to the reader as it is to Duras, as she remarks, "Comment ai-je pu écrire cette chose que je ne sais pas encore nommer et qui m’épouvante quand je la relis. Comment ai-je pu de même abandonner ce texte pendant des années dans cette maison de campagne régulièrement inondée en hiver ?" (12). "La douleur" thus demands to be read as a fossilized text, emerging in 1985 as an exact reproduction of the diary as it was written in 1945. "Le mot 'écrit' ne conviendrait pas," she writes, “Je me suis trouvée devant des pages régulièrement pleines d'une petite écriture extraordinairement régulière et calme. Je me suis trouvée devant un désordre phénoménal de la pensée et du sentiment auquel je n'ai pas osé toucher et au regard de quoi la littérature m'a fait honte” (12). According to Duras, there is nothing literary about "La douleur." Between her calm, controlled handwriting and the story that it tells, there is a breach so large that she cannot fathom how she would have been able to unite the two into a coherent narrative. The tendency of previous critics to conceive of "La douleur" as a text whose narrative is in service of the historical record thus ignores the complex relationship that exists between writing and the memory of the trauma the text describes. The driving question behind "La douleur" is not how to make sense of a traumatic experience while staying true to the historical record, but rather how the mechanisms of bearing witness and writing allow for the creation of a sense of meaning around a traumatic experience so steeped in uncertainty.

Originally used to refer to a physical, locatable wound, 'trauma' took on a second meaning in the late nineteenth and early twentieth century when added to the vocabulary 
of psychoanalysts such as Sigmund Freud and Jacques Lacan. Within the field of psychoanalysis, trauma still refers to a wound, though in this context the wound appears not in the body but in the mind and as such lacks the physicality associated with those of the body. Unlike physical wounds, which are more easily located and healed, psychological wounds indicate a rupture in the experience of time, self, and the world (Caruth 3). In other words, a traumatic experience is one in which the mind ceases, if only temporarily, to identify its surroundings, both spatial and temporal, as well as the self's own relationship to these places. Because this psychological wound is not as easily located it is all the more difficult to treat and to heal. The events that trigger this kind of perceptional breach occur too suddenly and too unexpectedly to be fully comprehended and consequently they resist full conscious assimilation (4). Existing beyond a distinct understanding of time and space, trauma defies language; consciously witnessing trauma through speech, a predetermined linguistic grid, inevitably distorts its true meaning. In this light, the discrepancies between the two versions of "La douleur" - the draft contained in Cahiers de la Guerre and the short story in La Douleur - do not detract from the emotional accuracy of either narrative; instead they are evocative of an author struggling to uncover the true nature of her own trauma. While historical accuracy speaks to the cooperative interaction between the historical record and a narrative that is inscribed within the particular moment in time, I use the term emotional accuracy to denote the extent to which feelings and impressions as they were experienced at the time are accurately portrayed in the text. It is this emotional accuracy as it pertains to recounting a traumatic experience that will be the focus of my research, for "La douleur" 
is above all else a narrative of trauma. Unable to know what has become of her husband, the narrator Duras oscillates violently between the hope that he will return and the certainty that he is already dead. In order to understand the meaning of such a harrowing experience shrouded in uncertainty, and to faithfully convey that meaning through writing, historical accuracy is inevitably eschewed, I will argue, due to the different modes of remembering involved in witnessing - in narrating - a traumatic experience.

I will foreground my investigation in a comparison of the two versions of the diary's events in order to show how each version - and within it the changes in voice, tone, mood, and tense - reflect the narrating Duras' relationship to the trauma she describes. I contend that these texts do not endeavor to represent events as they occurred in April 1945 from a historically objective perspective. Instead, when read together the two versions of the diary form an overarching narrative that speaks to the initial uncertainty and catastrophe of a traumatic experience and the inevitable forgetting that is integral to the act of narrating trauma. This process of bearing witness to a traumatic event or period is a necessary step toward finding meaning and achieving a sense of closure. I will begin with a reading of both versions of "La douleur" alongside each other. My intent in doing so is not merely to inventory the modifications made by Duras, but to devote particular attention to the manner in which what is articulated in excerpts from the version in Cahiers de la Guerre (henceforth denoted by $C G$, while $L D$ will be used to refer to the rewritten version) is reformulated through rewriting, and how this transformation reveals the progression from uncertainty toward understanding. The resulting changes between the two versions, I will argue, suggest that the narrating Duras 
of "La douleur" relies on two different modes of remembering when attempting to construct a narrative of her own traumatic past: deep memory and intellectual memory.

In the second chapter I will examine in closer detail how these different modes of remembering relate to the psychological impact of traumatic experiences, and the accompanying act of testifying or bearing witness. While no single unified theory of trauma exists due to its inherently subjective nature, there are certain mechanisms that all traumatic experiences do share. It is important to understand the development and function of these mechanisms for they will help to elucidate the purpose of deep memory and intellectual memory in "La douleur." Because trauma is at its core beyond language, I will demonstrate how the once fragmented and sensory memories of a traumatic experience are reformulated through language and become increasingly narratized - an act which necessarily erases the exact details of the event through the selective and organizing mechanisms of language.

In the last chapter I will compare the psychoanalytic understanding of the inevitable forgetting that arises through narrating to a post-structuralist understanding of the relationship between authorial identity and writing (and rewriting). I will argue that through rewriting "La douleur," Duras exerts a firmer sense of control over her traumatic past, but also embraces her own memory's infallibility. Bearing witness, like writing itself, revolves around mastering uncertainty. Duras' repeated attempt to reconstruct a complete and coherent narrative of trauma as it was experienced, in fact heightens the emotional accuracy of these narratives and provides a clearer picture of the mechanisms involved in witnessing and letting go. My goal in doing so is to advance the discourse 
surrounding "La douleur" beyond its utility and veracity as a historical document and to reassert these texts' individuality as one that simultaneously addresses what it means to uncover trauma and what it means to write.

Before proceeding to my own readings of "La douleur" I feel it pertinent to examine previous interpretations, specifically with regard to historical and emotional accuracy, as these previous interpretations do to some extent influence my own. Like the present study, these previous analyses focus primarily on the relationship between bearing witness and writing. However, many of these critiques were written before the original diary contained in Cahiers de la Guerre was published and consequently focus less attention on the evolving narrative. Yet these analyses do suggest several valid perspectives, which when accompanied by a theoretical understanding of trauma and readings of both versions of "La douleur," help create a more complete view of the relationship between remembering, witnessing, and writing trauma.

The first of these texts, "The Limits of Fiction," is a chapter from Leslie Hill's Marguerite Duras: Apocalyptic Desires. In his analysis, Hill notes that prior to La Douleur's publication in 1985 Duras had already adopted a new writing style, beginning with her journalistic prose in Les Yeux Verts and L'Été 80, that, like "La douleur," features a narrating Duras speaking to an unknown addressee. As this style differs from traditional fiction and non-fiction prose, in which it is implied that the author or narrator is directly addressing the reader, Duras creates a new authorial voice that allows her to blur, or even dismantle, the existing barriers between genres (115). Without having to adhere to the typical conventions of an established genre, Duras' texts become self- 
contained stories that are, at least in theory, devoid of outside influence and escape even Duras' authorial control, thus better reflecting her belief that writing was primarily an act of externalization and dispossession (117). No longer hampered by obligatory narrative coherency, a disorganizing force within the narrative takes over, one which often sacrifices historical accuracy in favor of "greater emotional density or immediacy" (120) - that is, greater emotional accuracy.

This particular kind of narrative voice is well suited to a work like "La douleur" as the focus of its narrative content is squarely placed on the emotions accompanying trauma. Hill does not question this, and further notes that through its ambiguities "La douleur" attests to the difficulty of representing the past, especially when "what has to be remembered cannot be adequately contained within the available boundaries" (124). Hill therefore claims that the modifications made to the first version of the diary (or, more precisely, to "Pas mort en déportation," for at the time of Hill's writing the texts that would become Cahiers de la Guerre were still tucked away in Neauphle-le-Château) were deliberate attempts to sabotage the clarity of her text, thereby heightening its dramatic intensity. These effects create a narrative that "bears witness to the sheer impossibility of bearing witness" (129) and, by extension, the difficulty of narratizing memories of a traumatic past.

While I do agree that "La douleur" addresses the intricacies of forming a narrative around an experience that defies language, I see Duras' editing not as a deliberate slip into fiction, but an inevitable result of witnessing, obliquely revealing to the process by which one bears witness and the changing forms of memory involved. Hill points to the 
narrating Duras' use of pronouns in "La douleur," - which frequently shift between the personal 'je' and the indistinct 'elle' - as evidence of Duras' disrespect for time-honored polarities: the fragile relationships between self and other, reality and fiction, and living and dying in order to create a new kind of literature. I will argue that these stylistic traits ('choice' may not be the correct word in this case) are neither created nor used solely in the name of creating literature, although this is certainly an unavoidable outcome. These traits instead signal an attempt to describe the journey from trauma and uncertainty to understanding and closure.

In “Spectres of Remorse: Duras's War-Time Autobiography,” briefly mentioned above, Gabriel Jacobs revisits the question of deliberateness and reliability in all the texts in the collection La Douleur. Like Hill, Jacobs agrees that a continuous theme in La Douleur is the conditions under which testimony is made possible and how Duras questions these conditions. For Jacobs, the organization of the narratives within $L a$ Douleur represents a "decrescendo" from autobiographical narratives ("La douleur" and “Monsieur X., dit ici Pierre Rabier”) to semi-autobiographical narratives (“Albert des capitales" and "Ter le milicien") in which Duras assumes the alternate identity of Thérèse but is careful to maintain their singleness: “Thérèse c'est moi. Celle qui torture le donneur, c'est moi. De même celle qui a envie de faire l'amour avec Ter le milicien, moi" ( $L D$ 138). The final two texts, "L’Ortie brisée" and "Aurélia Paris," are pure fiction,

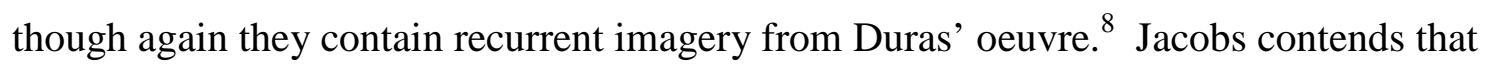

${ }^{8}$ In her brief introduction to "L'Ortie brisée" Duras states that she rewrote this text and that she no longer knows what it is about ( $L D$ 194), but that it sometimes seems to her that "l'étranger, je crois que c'est Ter le milicien qui s'est échappé du centre Richelieu" (LD 194). "Aurélia Paris" is 
by deliberately arranging the narratives this way Duras achieves an expiation of long-felt guilt (51), in which the faultless, martyr-like Marguerite of "La douleur" is juxtaposed with the torturing, vengeful Thérèse of "Albert des capitales" and "Ter le milicien," in order to expose humanity's shared capacity for both good and evil: "By the end of $L a$ Douleur, the confession is complete; literature has replaced repugnant memories of the real self during the period of the Occupation and the Liberation" (51). In this interpretation of "La douleur," guilt - not trauma - is the driving force of the narrative. But Jacobs also implies that this confession of guilt and its transformation into literature is somehow tainted by a self-indulgent Duras who compromises the accuracy of her narrative through her conflation of fact and fiction. Duras' claimed amnesia with regard to writing the original diary and its implied unedited status are merely constructs used to suggest the "repression of the memory of an unbearable series of events" (49) unbearable because of the guilt they induced, not their traumatic nature.

When both versions of "La douleur" are read together, the argument can certainly be made that the second version is indeed more "literary" than the first, which I will explore in further detail in the following chapters. However, such a transformation does not exclusively imply that Duras was unapologetically attempting to manipulate history, both in the personal and collective sense, or the reader of "La douleur." Furthermore, the guilt that Jacobs identifies in "La douleur" stems from Duras' desire to divorce Antelme so that she may bear Mascolo's child, news that she only breaks to Antelme after he has

a theatre piece written around the character Aurélia Steiner who appears throughout Duras's work, but never with a fixed identity. As Laura Adler puts it, "The name Aurélia Steiner belongs to no one" (320). 
recovered. Friends of Antelme confirm that he was crushed by this news, despite the open nature of their marriage, but within the second version of "La douleur" the narrating Duras claims that this was not new information to Antelme. It is implied that Antelme was aware of this desire before his arrest as the narrating Duras says she has not changed her mind in the last two years. While it is possible that over time Duras felt a growing sense of guilt regarding this episode, as this excerpt has no textual counterpart in the diary that appears in Cahiers de la Guerre, it is less likely that this episode alone, and any guilt it generated, was the impetus for her publishing "La douleur" in 1985. The traumatic event at the heart of "La douleur" is Robert's absence and the resulting possibility of his death. Describing her request for a divorce, as I see it, has less to do with a longstanding feeling of guilt and is instead representative of a symbolic separation from a man whose very existence had become the primary focus of Duras' day-to-day life during the Occupation. The textual representation of her request for a divorce further reasserts the sense of integrated individuality that is central to bearing witness.

Finally I would like to briefly examine a study of the second narrative in the collection La Douleur, "Monsieur X., dit ici Pierre Rabier.” In the first chapter of Telling Anxiety: Anxious Narration in the Work of Marguerite Duras, Annie Ernaux, Nathalie Sarraute, and Anne Hébert, author Jennifer Willging examines the narrative "particularities" (30) of "Monsieur X." namely, changes in tense, mood, and voice which Hill and Jacobs would identify as deliberate or premeditated means used to address the difficulty of bearing witness. As with the previous analyses I have discussed, Willging also sees "Monsieur X." as a narrative that is, if only peripherally, about bearing 
witness to a difficult past. But unlike her predecessors, Willging acknowledges that what may be responsible for these narrative particularities is not Duras' desire to obfuscate the truth, but the complex relationship between remembering and narrating.

"Monsieur X." precedes the events narrated in "La douleur," taking place in the summer of 1944, just after Robert Antelme's arrest. In this narrative, as in "La douleur," Duras employs the first person to recount her relationship with the German Gestapo agent, Pierre Rabier ${ }^{9}$, who was responsible for her husband's arrest. Willging maintains that "Monsieur X." recounts a particularly traumatic episode from the Occupation (as I propose with regard to "La douleur"), for Rabier was, in a way, courting Duras.

Fascinated by French intellectuals, Rabier takes a particular interest in Duras, inviting her to cafés and restaurants, glad to now be affiliated with the milieu he so admires. Duras writes that she only maintained contact with Rabier in the hopes of receiving information about her husband's whereabouts and because François Morland, the nom de guerre of François Mitterrand as leader of the MNPGD, told her to do so. But maintaining a relationship with the officer responsible for so many arrests and who also essentially held Duras' fate in his hands was, as Duras writes, "terrifiant à vivre, au point de pouvoir en mourir d'horreur" (LD 90), clearly signaling, according to Willging, that this was indeed a traumatic period of her life.

\footnotetext{
${ }^{9}$ Like 'Robert L.,' 'Pierre Rabier' is also an alias. His real name was Charles Delval and he was arrested, tried, and executed after the Liberation. Duras notes in her introduction to "Monsieur X." that it is only out of respect for the privacy of his wife and child that she does not use his real name.
} 
Among the narrative particularities noted by Willging in "Monsieur X." is a recurring shift in distance between what she refers to as the narrator-I and the character-I. Both are meant to be textual representations of Duras, but while the character-I never leaves the temporal space of June 1944, the narrator-I speaks both from the position of the character-I as well as an unspecified point in the future. Willging cites one instance where this shift is made early in the narrator's description of her relationship with Rabier, in which she remarks, “[Rabier] prétend qu'il lui [Robert Antelme] a évité un jugement et que mon mari est maintenant assimilé aux réfractaires du S.T.O. Moi aussi je le tiens: si j'apprends que mon mari est parti en Allemagne, je n'ai plus besoin de le voir, et il le sait. L'histoire du S.T.O. est fausse, je l'apprendrai plus tard" ( $L D$ 99). Though the narrator-I speaks primarily in the present tense, suggesting the unity of the narrator-I and the character-I and underscoring the emotional immediacy of its content, the narrator-I who remarks "je l'apprendrai plus tard" is different from the united narrator/character-I who had begun speaking. Speaking from a different present, as in the excerpt above, disrupts the chronology of the narrative and Willging observes that a prolepsis such as this suggests "that the narrator-I wishes to disabuse the reader as quickly as possible of misinformation that a faithful, present-tense transcription of the 'naive' (that is, without hindsight) character-I's perceptions and thoughts would give" (36). This naturally lends some credence to the arguments of critics like Hill and Jacobs who question the verisimilitude of the autobiographical narratives in La Douleur since the struggle for dominance between the two temporally distinct narrating selves implies that neither one is completely capable of accurately recounting events as they actually occurred. This 
conflation of past, present, and future is present in both "Monsieur X." and "La douleur" and reveals, albeit indirectly, the process of remembering and intellectualizing in the acts of writing and rewriting.

However, unlike critics who are quick to disavow the validity of "La douleur" or "Monsieur X." as accurate representations of the past based solely on their narrative inconsistencies, Willging suggests that the presence of a prolepsis like the one described above serves as a reminder that what is being recounted belongs to a "finished and determined past" (34). By speaking from a present tense detached from the present of June 1944, the narrator-I is able to emotionally distance herself from the character-I and a difficult episode in her personal history. This separation between the character-I and narrator-I mirrors the psychoanalytic process of bearing witness to a traumatic memory, which I will examine in further detail in the second chapter. The two distinct narrating selves present in the narrative are, according to Willging, indicative of two very different modes of remembering trauma. When the speaking narrator-I and character-I represent a single entity, the resulting narrative emanates from mémoire profonde, or deep memory, which endeavors to remember the self as it was. Willging describes deep memory as the persistence of the past in its own perpetual present, noting that deep memory is more faithful to the lived experience and retains impressions in sensations, not in words, and in the body, not in the intellect (43). Deep memory thus endeavors to preserve the raw emotion of the event in question. Willging refers to the second mode of remembering present in "Monsieur X." as mémoire intellectuelle, or intellectual memory. Whereas deep memory seeks to preserve the self and emotions as they were in the past, intellectual 
memory reworks the raw impressions of these memories, subduing their emotional force and organizing them into a more lucid, intelligible narrative (42). These two modes of remembering were first outlined by Holocaust survivor Charlotte Delbo in La Mémoire et Les Jours (1985), the last installment of her four volume memoir Auschwitz et Après. For Delbo, intellectual memory not only organizes and rationalizes, but also provides reassurance against the overwhelming grief of deep memory that threatens to erupt into consciousness. Though Duras herself was never arrested, never deported, and never subjected to the same atrocities as were the millions of Jews, Communists, Roma, Résistants, and other French citizens deemed undesirable by Nazi Germany, the fear and anguish with which she lived under the Occupation produced a day-to-day life that was similarly tortuous and traumatic. Duras, too, risked her own life through her connection to and work with François Mitterrand and the Résistance. Intellectual memory and deep memory as described by Delbo therefore need not be exclusively reserved for Holocaust survivors; they are applicable to narratives of trauma in general, including "Monsieur X.," as Willging maintains, and "La douleur," as I suggest. If we consider again that trauma defies language through its refusal to be fully assimilated into consciousness, then constructing a narrative of trauma inevitably involves translating sensory memories into a shared, common lexicon. Constructing a narrative based on what is only felt, or attempting to recognize the unrecognizable, inevitably weakens the total accuracy of the initial memory, as language endeavors to construct a linear, verbal account of impressions - sights, sounds, feelings often experienced simultaneously and, above all else, subjectively. As Duras recalls the traumatic episodes of her past, whether they be 
from the period during which she frequented Rabier or the agonizing wait for news of her husband, the emergent narrative can only be an "approximate, linguistic, as well as narratized, transcription" (43).

I reference the three studies above, and Willging's in particular, because I would like to propose a new reading of "La douleur," one which places emphasis not on the authenticity of "La douleur" as an autobiographical narrative, but on its validity as an accurate narrative of trauma. Like "Monsieur X.," the two versions of "La douleur" when read together exhibit the same tension between intellectual memory and deep memory, a tension which Duras herself seemed to be acutely aware of. In La Douleur, both the diary and "Monsieur X." begin with a preface that insists on the veracity of each narrative (despite Duras' claimed amnesia regarding her writing “La douleur”). Duras' assertion that she has no memory of writing this version of "La douleur" but knows its contents to be true is later echoed in her preface to "Monsieur X." in which she says, "il s'agit d'une histoire vraie jusque dans le détail," (LD 90). Both narratives speak to the overwhelming, sometimes incapacitating anguish Duras experienced after her husband's arrest and deportation. By testifying to the narrative's truthfulness before the reader can proceed, Duras legitimizes the presence of her own intellectual memory and its efficacy as a conduit for her deep memory. The importance of the factual accuracy of the quotidian the description of the setting, who was there, and what was said - is second to a faithful representation of how Duras experienced these events. 


\section{Chapter I}

\section{Remembering Trauma: Recalling the Uncertain}

While each version of "La douleur" reveals the same central figure and the same scenarios, their articulation in each of the two accounts is dramatically different. In the original diary, the narrative is unmistakably emblematic of the same style of writing that

she claims to espouse in her book of essays Écrire: "Chaque livre comme chaque écrivain a un passage difficile, incontournable. Et il doit prendre la décision de laisser cette erreur dans le livre pour qu'il reste un vrai livre, pas menti" (42). The first version of "La douleur" (included in Cahiers de la Guerre) indeed more closely resembles this unrevised style of writing, resembling a continuous, unorganized flow of raw impressions. The way in which this erreur is reformulated - not removed - from the first to the second version allows Duras to accurately represent her psychic state, both from the point of view of her 1945 textual self and her present authorial self. To illustrate this point it is worth examining several excerpts from both versions of "La douleur" in order to discern the ways in which the initial raw impressions of deep memory are articulated in the first version and reformulated, and to what extent, by intellectual memory in the second.

Violence abounds in the first version of the narrative, and Duras' narrating self is both victim and perpetrator. As she repeatedly and involuntarily visualizes horrifying images of her husband's fate she is seized with grief, as she is unable to help him. The repetition of specific words, like 'Mort,' and variations of the question 'Où est-il ?' echo 
the recurrence of these visions throughout the narrative $(C G$ 198, 202). Similarly, this grief inspires a desire for revenge in the narrating Duras: for example, she imagines herself gouging out the eyes of a German soldier ( $C G$ 200) and assaulting the women of Germany who bemoan the loss of their men ( $C G$ 194). This back and forth between a narrating self that is alternately yearning for violence and paralyzed by anguish reveals the circular thinking of an obsessed mind, and her rage and distress are unleashed unremittingly in the narrative, frequently directed at not only the Germans, but also General de Gaulle for his failure to adequately address the issue of French deportees. "Il n’ose pas parler des camps de concentration," she says, "il répugne manifestement à intégrer les pleurs du peuple dans la victoire de peur de l'affaiblir, d'en diminuer la portée" (CG 214). Describing one of de Gaulle's recent speeches, referred to only as "Discours du 3 avril 1945" (CG 213), in which he lauds the symbolic importance of Paris and trumpets the happy days to come after the Liberation, the narrating Duras displays the full force of her hatred and disdain of de Gaulle's perceived indifference. Dedicating three pages to condemning his actions and fanaticism, she goes so far as to declare that the only difference between de Gaulle and Hitler is that de Gaulle is a Catholic: "La différence entre de Gaulle et Hitler, c'est que de Gaulle croit en la transsubstantiation ... Hitler croit dans la force venue d'en haut. De Gaulle croit à la force venue d'En Haut" (CG 213). This vitriolic polemic, unleashed without reverence appears in part in the rewritten version of "La douleur," though it has been considerably abridged and places less emphasis on de Gaulle's religious zeal. While it is uncertain how the conflation of de Gaulle and Hitler would have been received in France during the 1980s - a time when the 
nation was finally lifting the screen of Résistancialisme and acknowledging France's collaboration with Nazi Germany - the measured tone that appears in the second version subdues the violence of the first, and thus lessens the alienating effect the first may have had were it published as-is.

More importantly, by quieting (but not silencing altogether) the violence found in the first narrative, Duras transforms her previously callous and angry narrating-self into a more sympathetic and rational one, thereby adopting a tone that is no longer driven by the violence of her raw impressions but instead reveals a composure achieved through distance and reflection. A similar reformulation occurs when in the first version her thoughts turn to Berlin's ensuing demise:

Je rêve d'une ville idéale, brûlée, entre les ruines de laquelle coulerait le sang allemand. Je crois sentir l'odeur de ce sang, il est plus rouge que le sang de bœuf, il ressemblerait au sang de porc, il ne se coagulerait pas, il coulerait loin, et sur les bords de ces rivières, des femmes en larmes auxquelles je foutrais des coups de pied au cul, et que je basculerais le nez dans le sang de leurs hommes. Les gens qui en ce moment-ci, ce jour-ci, éprouvent une pitié pour l'Allemagne, ou plutôt n'éprouvent pas de haine à son égard, me font pitié à leur tour. (CG 194)

The narrating Duras sees Berlin burning, smells the odor of German blood, physically harms the women of Germany, apparently indifferent to the pity this act inspires in others. She voices her immense anger from this period without restraint. In this excerpt the raw impact of this episode is maintained without any attempt to soften or intellectualize the force of these feelings; she is enraged. Yet in the second version of " $\mathrm{La}$ douleur" this passage is rewritten in a manner that completely erases her personal desire for violence: 
Berlin flambe. Elle sera brûlée jusqu'à la racine. Entre ses ruines, le sang allemand coulera. Quelquefois on croit sentir l'odeur de ce sang. Le voir. $(L D 34)$

Here there is a much stronger element of restraint in the simple fact of the considerable decrease in length that has occurred between the first and second version. This restraint is further articulated through the second excerpt's erasure of the selfreferentiality present in the original, raw version, which allows for the dissociation of author from textual self. Here, the antagonistic narrating-self of the first version is removed, replacing "je" with the impersonal "on" and suppressing any suggestion of a desire to inflict physical harm. As a result, the personal desire for violence is quieted and absorbed into an indistinct 'on,' while the hypothetical violence of the first excerpt (denoted by the French conditionnel in "coulerait," ressemblerait," "coagulerait") is replaced with the more factual futur simple, which expresses the certainty that Berlin will be destroyed ("elle sera brûlée"). The feelings that were once specific to the narrating Duras in the first excerpt are described in the second in generalized, neutral terms that reveal a voice informed by the shared knowledge of a common history. In this way, the narrating Duras' intellectual memory subdues the overwhelming violence and unrefined detail of her deep memory, depersonalizing its content and separating the author from a painful memory.

This same kind of depersonalization occurs throughout the second version of "La douleur" as the narrating Duras reshapes passages that previously contained the personal pronoun 'je' and replaces them with a less distinct 'nous,' 'on,' or 'elle.' These substitutions, which are not made uniformly, reflect the ongoing tension between deep 
memory and intellectual memory. The sheer anguish described resists a complete reorganization or rationalization; the narrating Duras of the second version can only separate herself from this memory by assigning it to an indistinct, unspecific other. In an episode described in the original diary contained in Cahiers de la Guerre, the narrating Duras experiences a moment of overwhelming uncertainty and is desperate for the comfort her lover, Dionys Mascolo, will provide for her. She says,

$\mathrm{D}$ [ionys] le sait qui je suis . Où est D. ? Je peux le voir et lui demander des explications. (CG 220)

In this excerpt "je" signifies the singularity of the narrating Duras and the central figure in the narrative, but in the same excerpt from La Douleur, she says,

Qui elle est, D. le sait. Où est D. ? Elle le sait, elle peut le voir et lui demander des explications. ( $L D 50)$

Here a distinction is made between the two voices, suggesting that the narrating Duras ("je") and the Duras in the text ("elle") are no longer the same woman. As the temporal distance increases between the initial writing and subsequent rewriting of the diary, Duras comes closer to a sense of closure regarding the traumatizing events of the war, but can no longer fully identify with the "je" of the first narrative.

Similarly, in one of the most frenzied passages in the text, the narrating-self is suddenly certain that her husband is dead; she feels herself coming undone and is no longer sure of who she is, where she is, what she is waiting for, and what the name 'Robert' even signifies ( $C G 219, L D 49)$. In the original diary, this episode begins with a simulated dialogue in which the narrating Duras fills the role of both interlocutors: "Je ne sais pas où il se trouve. Je suis avec lui. Où? Avec lui. Où avec lui? Je ne sais pas, avec 
lui. Où ? Je ne sais plus" (CG 219). She continues, adopting the informal 'tu' to refer to herself:

Plus rien de commun entre cet homme et toi. Qui est-ce Robert Antelme ? A-t-il jamais existé ? Qu'est-ce qui fait qu'il est Robert et pas un autre ? Au fait, dis-le un peu. Qu'attends-tu comme ça? Qu'est-ce qui fait que tu l'attends, lui et pas un autre. Qu'est-ce que tu fous après quinze jours à te monter le ciboulot? Qui es-tu ? (CG 219)

While this 'tu' typically connotes the other, the previous "dialogue" allows the reader to see that the 'je' and 'tu' of this episode are one and the same. By contrast, the second version of this same episode is retold in a tone that is more prosaic than conversational. Abandoning the interrogational mode of the first version, the narrating Duras begins with three definitive statements: "Je ne sais plus où il se trouve. Je ne sais plus non plus où je suis. Je ne sais pas où nous nous trouvons" ( $L D 49)$. She continues:

Plus rien de commun entre cet homme et elle. Qui est ce Robert L. ? A-t-il jamais existé ? Qu'est-ce qui fait ce Robert L., quoi ? Qu'est-ce qui fait qu'il soit attendu, lui et pas un autre ? Qu'est-ce qu'elle attend en vérité ? Quelle autre attente attend-elle ? À quoi joue-t-elle depuis quinze jours qu'elle se monte la tête avec cette attente-là ? Que se passe-t-il dans cette chambre ? Qui est-elle ? (LD 50)

Though the uncertainty and confusion at the core of this episode are retained in the second version, they are rearticulated in a more rhetorical manner, examining not only the pain of waiting for her husband, but the more general anguish of unfulfilled expectation. The question from the first excerpt, "Qu'est-ce qui fait que tu l'attends," in which 'tu' represents the narrating self who is waiting for her husband, becomes depersonalized through the removal of the narrating self in the second version's equivalent: “Qu'est-ce qu'il fait qu'il soit attendu.” By speaking in a more generalized manner and removing herself as subject, Duras transforms the second version of this 
passage into a depersonalized and ordered narrative, shifting closer to the voice of intellectual memory. The waiting that she describes no longer belongs to her own personal history but addresses waiting as a general concept. Though this intellectualization cannot entirely succeed in replacing the initial ineffability of deep memory, these changes, as Hills affirms, allow for the act of bearing witness to reach beyond the private realm; testimony is no longer purely "a private act, authorized solely by personal experience" (126). In his book Holocaust Testimonies: The Ruin of Memory, Lawrence Langer notes that the use of such writing strategies when creating a narrative of trauma narrow the space between the author's memory and intent and the reader's capacity to absorb what the author has endured (19).

In this light, deferring to intellectual cognition when describing a painful memory embodies the narrating Duras' attempt to preserve the emotion of the experience despite, Langer asserts, "the limited power of words to release the specific kinds of physical distress haunting the caverns of deep memory" (8). The urgency and anguish present in the narrative are not eliminated by the voice of intellectual memory; rather their emotional force is subdued through poetic language that ushers the reader into an otherwise unfamiliar world. Let us consider an episode from the first version of "La douleur" in which the narrating Duras describes eating dinner in her apartment after another day of unbearable waiting:

On se met à table. Deux assiettes sur la table de la cuisine. Je tire le pain du placard. Du pain de trois jours. Une pause. Je dis à D.: « Le pain a trois jours. Tout est fermé à cette heure-ci... » On se regarde avec D.: «Vous parlez... », dit D. On pense la même chose à propos de ce pain. On commence à manger. On s'assied. Le morceau de pain dans ma main, je le 
regarde. J'ai envie de vomir. Le pain mort. Le pain qu'il n'a pas mangé, manquer de pain l'a fait mourir. Ma gorge est fermée, il n'y passerait pas une aiguille. Le pain, le goût du pain qu'il n'a pas mangé. (CG 181)

This meditation continues for another 23 lines, reflecting further on the photos of concentration camps that are now being released, ${ }^{10}$ the incomprehensible ability to maintain religious faith, and all those who are still able to eat bread, all of whom are, in her opinion, less deserving of this privilege than her husband. Yet in the rewritten diary this same reflection appears thus:

On s'assied pour manger. Aussitôt l'envie de vomir revient. Le pain est celui qu'il n'a pas mangé, celui dont le manque l'a fait mourir. J'ai envie que D. parte. ( $L D$ 19)

The first passage reveals a narrating Duras who is very much in the present; her thoughts run rampant and as she describes them she makes no effort to censor herself. Conversely, the second narrative is indicative of Duras' intellectualization of this same memory. The same thoughts and feelings are conveyed not through the subjective voice of an antiGaullist narrating self but through their form. Paring down her prose in this way effectively replicates the same feeling of mental confinement through sentences that are brief, yet direct. The reformulation of this episode also allows the narrating Duras to create a more accessible narrative, particularly through her removal of her ironic, and potentially alienating, observation that those who, at this moment, are consuming bread do so in part because they are able to ignore the true horror of the war:

\footnotetext{
${ }^{10}$ Though many had their suspicions regarding the true purpose of the German concentration camps, it was not until Allied forces began liberating the camps in 1945 that the truth was made public, through talks given by survivors, newspaper reports, and photos (Koreman 16).
} 
Pendant la Libération, à l'heure où le moment d'égorger était venu, ils prêchaient déjà l'indulgence et le pardon des péchés. Le pain de cureton : Prenez et mangez, ceci est mon corps. Le pain de l'ouvrier agricole. Le pain de la bonne toujours-mangé-à-la-cuisine : « Nous avons une bonne qui mange plus que sa carte! Pensez, Madame, c'est épouvantable des gens pareils. » Le pain gagné. Le pain tout cuit payé par le papa capitaliste à son petit rejeton chéri qui, en ce moment même, s'intéresse à la guerre. (CG 182)

Removing this excerpt and other similarly contemptuous passages from the second version does indeed subdue the emotional immediacy of the first version, a dilemma that I will address in more detail in chapters to come. However, the voice of intellectual memory that emerges in the second version, substantiated by information gathered after the war, allows the narrating Duras to achieve a sense of certainty through the more coherent narrative that coalesces. Given trauma's inherently ambiguous nature, bearing witness to it, that is, naming and communicating what begins as an unknown, requires that the experience be inscribed within distinct historic and linguistic boundaries. We may therefore think of the rewritten version as a text whose narrative content more narrowly conforms to the established criteria of shared language - what Derrida has referred to as "a network [une grille] that is communicable, transmittable, decipherable, iterable for a third, and hence for every possible user in general" (8). In this light, Duras' use of a more systematic language in the second version allows her, as author and witness, to better identify the details of her traumatic experience, thereby making sense of an otherwise indescribable experience.

I refer to this concept of repeatability in communication as I feel that it mirrors the implicit objectives of intellectual memory: to create an intelligible and recognizable, that is to say linguistic, narrative based on the essentially visceral impressions of deep 
memory. What distinguishes the rewritten "La douleur" from its predecessor is the discernible struggle to faithfully recount the memory of an episode that constantly threatens to defy the imposed order of language and disintegrate into ineffable fragments. An example of this struggle can be found in the following two versions of the same episode, in which the narrating Duras is suddenly certain her husband is dead:

Tout à coup. Peur. «Mais tu ne vois pas qu'il ne reviendra jamais ? » Plus que ça. La glace dans le cœur. Je me suis retrouvée dehors, chassée. Une fois dehors, je me suis dit: «J'ai le temps d'aller et revenir avant le dernier métro. » Panique. La fuite, c'est ça. La sueur sur tout le corps. Du nouveau dans l'attente. Tout à coup j'avais relevé la tête, et l'appartement était tout changé et la lumière de la lampe n'était plus la même. Quelque chose menaçait. Menacé de tous les côtés. Tout à coup la certitude, la certitude, la certitude. Il est mort. Mort. Mort. Mort. On est le vingt-sept avril on est le vingt-sept avril on est le vingt-sept avril. Mort Mort Mort. Le silence. Le silence. Silence. (CG 218)

This excerpt, with its indistinct 'tu' and fragmented sentences captures the essence of impressionistic deep memory. The identity of the one who asks, "Mais tu ne vois pas qu'il ne reviendra jamais?" is unclear; no attempt is made to guide the reader through these jumbled thoughts, as though the memory of this episode resists complete articulation and its description is still a form of private speech. In this version of the text, emotions hover menacingly, unclaimed, never disappearing completely. Their presence is announced with short, static sentences - "Peur," "Panique" - more like stage instructions for the theatre than a diary. As though struggling to properly orient herself in time and space, the narrating Duras jumps from thought to thought without transition, speaking in a mix of past and present ("Mais tu ne vois pas qu'il ne reviendra jamais?", "Je me suis retrouvée dehors"). Lastly, Duras' obsessive repetition of the words 'Certitude' and 
'Mort' resemble a kind of mantra, as if repeating these words will sharpen her focus, allowing her to fully comprehend the reality of Robert's death. Yet in their second incarnation, a relationship is established between these feelings and the place and time of their appearance:

Sur le coup de dix heures, tout à coup, chez moi, la peur était rentrée. La peur de tout. Je m'étais retrouvée dehors. Tout à coup j'avais relevé la tête et l'appartement avait changé, la clarté de la lampe aussi, jaune tout à coup. Et tout à coup la certitude, la certitude en rafale: il est mort. Mort. Mort. Le vingt et un avril, mort le vingt et un avril. (LD 49)

Here, intellectual memory relies on metaphoric language ("la certitude en rafale") instead of repetition to convey Duras' unrelenting fear. The ominous, all-encompassing "Peur," belonging to no one and everyone, is now specified as a fear with which she is already familiar, ("la peur était rentrée"). Her own fear becomes distinct as it now possesses a referent ("la peur de tout"), and is externalized through its personification; its return suggests that it is also capable of disappearing, thus losing the ominous quality assigned to fear in the first version of this excerpt. Describing her fear through a detour into metaphorical language also signals a newfound control over her emotions, for this kind of rhetoric softens the opacity and confusion found in the first version of this episode. While the second narrative retains some of the franticness of the first, it has been considerably quieted, demonstrating once again that intellectual memory not only renders its subject more intelligible but also dulls the sharpness of the initial feelings associated with the episode in question. Furthermore, the evidence of intellectual memory's ineluctable modification of the past can be found in the change of date between the two passages (from April 27 to April 21), indicating that when revisiting the original text 
before publication, Duras was forced to evaluate her work (at least somewhat) more objectively.

In fact, though much of the diary's narrative in both Cahiers de la Guerre and La Douleur is written in the present tense, creating the illusion that the events described in the diary were recorded as they were happening, there are frequent intrusions by a narrating self who speaks entirely from intellectual memory. Within the first pages of the diary, a phone call from an unspecified "elle" is described, in which the narrating Duras hears of Bergen-Belsen's liberation. What should be encouraging news leads only to more anxiety: one more camp liberated, and still no news of her husband. ${ }^{11}$ Thinking of the lists of deportees that will be published in the newspapers the following day, she describes the growing throb she feels at her temples:

Si le battement dans les tempes continue. Avant tout, arrêter les battements dans les tempes, on peut en mourir. La mort est en moi - Elle bat à mes tempes - On ne peut pas s'y tromper - Arrêter le battement dans les tempes - Arrêter le coeur - Le calmer - Il ne se calmera pas tout seul, il faut l'y aider - Arrêter l'exorbitation de la raison qui fuit et sort - Je mets mon manteau. Palier. Escalier. « Bonjour, Madame Antelme. » Concierge. (CG 177)

By confining the narrative to the present tense, a sense of immediacy is created that heightens the suspense and indeed achieves, as Hill notes, a more dramatic effect. The narrating Duras describes her thoughts and surroundings with fragments and imperatives,

\footnotetext{
${ }^{11}$ Nearly two million French citizens were deported under the Vichy Regime, of which approximately sixty percent returned. Though the liberation of concentration camps began in January 1945, repatriation proved to be a prolonged process. In October 1945 the French government declared that no more deportees could be expected to return from Poland or the USSR, closing the Ministry of Prisoners, Deportees, and Refugees at the end of that year (Koreman 21).
} 
effectively doing away with proper syntax, referents, and linearity. Deprived of these textual navigational tools, the reader cannot properly interpret the emotion expressed in this fragmentary language. Without regular punctuation, distinct subject pronouns (“Arrêter le battement dans les tempes - Arrêter le cœur - Le calmer”), or determiners ("Palier. Escalier ... Concierge"), this first version more closely resembles the imprecision of deep memory and makes the narrative nearly impenetrable. Yet in the second version, the above excerpt is reformulated to include these formerly absent elements:

Le battement dans les tempes continue. Il faudrait que j' arrête ce battement dans les tempes. Sa mort est en moi. Elle bat à mes tempes. On ne peut pas s'y tromper. Arrêter les battements dans les tempes - arrêter le coeur - le calmer - il ne se calmera jamais tout seul, il faut l'y aider. Arrêter l'exorbitation de la raison qui fuit, qui quitte la tête. Je mets mon manteau, je descends. La concierge est là: « Bonjour madame L. » (LD 15)

While certain elements that create a fragmented, impressionistic style of narration are maintained, the narrating Duras also inserts herself into these events at key moments, making herself distinct from her surroundings and naming her relation to them ("Il faudrait que j'arrête ce battement," "Sa mort est en moi," “La concierge est là"). As 'je' also implies a 'tu,' or a distinct other, the experience described is now more explicitly claimed to be her own, for this 'je,' acting as a written signature, "implies the actual or empirical nonpresence of the signer" (Derrida 20). Duras thus records and retains her "having-been present in a past now or present [maintenant] which will remain a future now or present" (20, original emphasis). Furthermore, by assigning the simple determiner 'la' to “concierge," Duras ascribes a certain familiarity to her concierge, moving her from the realm of the indistinct to the specific. Similarly, the transformation of "la mort' into 
"sa mort" removes the generalized, hypothetical connotation of 'death' in the first version and replaces it with a distinct referent, specifically becoming Robert's death. Unlike the previous excerpts I have examined, in which the narrative tone moves from the personal and specific to the impersonal and general, the transformation that occurs within the two versions of this episode suggests a movement from the general to the specific. However, in this case what becomes specified ("Sa mort," "La concierge") actually allows Duras' narrating self to delineate between herself and her surroundings, thereby exacting a newfound control over her self and her impressions. Transforming, for example, a phrase like "Palier. Escalier," into "je descends," indicates that the self and the present are once again integrated, providing a clear articulation of her temporality and, by extension, a greater control over her distinct self within that temporality. The effect is a narrative that is more transparent to the reader in terms of its psychic and emotional significance.

It is also worth noting that in this latter passage, naming the person identified as 'je' (Madame Antelme, madame L.) also functions as a means by which the narrating Duras is designated as separate from the author Duras. In the first excerpt "Madame Antelme," Duras' married name, indicates the unity between author and narrator. By assigning a pseudonym, "madame L.," to the narrating self in the rewritten excerpt, the author Duras signifies that the two are now dissociated entities. While replacing her own name with an alias can be construed as a detour into fiction, it is also evocative of the finished and determined past previously mentioned by Willging (see page 16 of the introduction). In the first version, written in or around 1945, the memory of this moment has not yet been filtered by an intellectualized memory; it is still raw and unprocessed, it 
still belongs to Madame Antelme. Rewriting "La douleur," the author Duras can no longer wholly identify with this persona, as the voice of intellectual memory that reshapes this passage belongs not to Madame Antelme, but to Duras, who had nearly 40 years to reshape this memory. Put another way, the memory of this episode has been transferred to a new, distinct speaking subject, madame L., allowing Duras, in her role as author, to effectively separate herself from the memory and its emotions. By ascribing the memory to another, its meaning becomes increasingly interpretable and communicable.

The voice of intellectualized memory further presents itself in the narrative through shifting present tenses that represent both 1945 and a less distinct present, which may be called the present of the text, as the narrating Duras that speaks from this second present possesses knowledge that would not have been available in present 1945. Two distinct narratives are thus created through these two distinct narrating selves: one speaks from the present of the events in the story and endeavors to recount them as though they are occurring in present 1945, while the other, speaking from the present of the text, continually assigns these events to another temporality - a temporality which, though not the past, is also not entirely in the contemporary present. An example of one such shift occurs when the narrating Duras describes her neighbor, Madame Kats, waiting for her daughter who, like Duras' sister-in-law, has also been deported to Ravensbrück:

Sa fille est infirme, elle avait une jambe raide à la suite d'une tuberculose osseuse, elle était juive. J'ai appris au centre qu'ils tuaient les infirmes. Pour les juifs on commence à savoir. Mme Kats a attendu six mois, d'avril à novembre 1945. Sa fille était morte en mars 1945, on lui a notifié la mort en novembre 1945, il a fallu neuf mois pour trouver le nom. (LD 58) 
Given that this excerpt comes from an entry dated "27 avril," the information regarding the death of Madame Kats's daughter can only come from a narrating self that speaks in the present of the text, who already knows about the details of the Holocaust. Yet this particular narrating Duras does not always assert herself in the face of unbearable uncertainty, despite her ability to both intellectualize her feelings and imbue them with a sense of reassurance achieved through her historically informed position. Instead, her irregular presence signals the ongoing push and pull between deep memory's fundamental refusal to lay the past to rest and intellectual memory, which strives to recognize and name the unknown. Deferring to this intellectualized mode of remembering in the text allays the intensity of the anguish Madame Kats feels for her daughter and supplies the crucial information that was lacking in April 1945.

A similar shift is found in an entry dated " 20 avril," in which the narrating Duras, in the rewritten version, describes the arrival of a convoy of deportees to the Orsay Center where she is working. There is only a single narrating self, until she says:

Ils mangent, et tout en mangeant ils répondent aux questions qu'on leur pose. La chose frappante c'est que ce qu'on leur dit ne semble pas les intéresser. Je le saurai demain par les journaux, il y a parmi ces gens, ces vieillards: le général Challe, son fils Hubert Challe qui devait mourir cette nuit-ci, la nuit même de son arrivée ..." ( $L D 32$, emphasis mine).

This prolepsis negates the sense of immediacy and uncertainty created by a single present tense, as the narrating Duras that takes over with her use of the future tense knows what will happen the next day and what was going to happen that night. These passages demonstrate an almost impulsive shift toward intellectual memory, with its reassuring ability to mediate uncertainty by availing itself of the historical record. Delbo 
refers to this particular mechanism of intellectualization as "common memory" (Langer 5) when describing her memories of Auschwitz. Common memory, Langer writes, with its talk of normalcy amid chaos mediates atrocity and sedates the surge of deep memory that constantly threatens to erupt (8). The disruption in this episode of the bond between the narrating Duras of present 1945 and of the narrating Duras in the present of the rewritten text of the 1980s reflects the inevitable shift toward a mode of remembering that soothes the anguish of her interminable wait for her husband - an anguish which, it seems, still cannot be completely assimilated into the past.

Curiously, the two prolepses I have described exist in both versions of "La douleur," indicating that the version contained in Cahiers de la Guerre must have been edited as well. In a 1985 interview with Marianne Alphant in the newspaper Libération, Duras admitted, “À mon avis, j’ai dû commencer à écrire La Douleur quand on est allé dans des maisons de repos pour déportés" (Alphant 37). This speculation at least partially supports Duras' stance in her preface to the rewritten version of "La douleur" ["Je n'ai aucun souvenir de l'avoir écrit" ( $L D 12)]$. It is true that Duras and Antelme visited several convalescent homes after he had returned to France and been "restored" to health. If Duras' remark was in fact true, and she did begin to rewrite the diary as early as 1946, it would explain the presence of this specific prolepsis in both versions. Yet trusting Duras in this assertion regarding the origins of "La douleur" is certainly a dubious enterprise. By 1985 Duras' memory was clearly faltering under the weight of years of alcoholism. Regardless of the exact time at which Duras began rewriting the diary, the two versions nevertheless depict two modes of remembering that vacillate in their 
prominence, revealing the process by which memories of a traumatic past become recognizable, describable and locatable, able to be externalized and inscribed within a larger historical context. Like deep memory and intellectual memory, which represent a shift from the indistinct to the recognizable, trauma also begins in the unconscious, the space between consciousness and perception (Lacan 56) and arcs toward the conscious and defined, thereby moving the act of witnessing and narrating from the private realm to the public.

When both versions of "La douleur" are read together in this way, it becomes clear that narratizing memories of a traumatic past is an ongoing process, characterized by the tension that exists between the dual modes of remembering I have described. Both deep memory and intellectual memory work together to remember the self as it was, and describe, in the present, the psychic state of this past self, inevitably reshaping memories of trauma in order to build a complete narrative. While deep memory attempts to preserve the self as it was in the past - including the impressions of the unrecognizable, the subjectivity of deep feeling, and the imprint of the indescribable - the true impact of these elements inevitably disappears into the language of intellectual memory. Though the first version of "La douleur" features a narrating Duras whose descriptions hew closer to the sensory and subjective aspect of her wait for Robert, her conflation of past and present already reveal the tendency to intellectualize and revert to common, informed memory. Likewise, the sensory aspect of the first version of "La douleur" is not wholly absent from the second version, though in this case the sensory experience is condensed and either depersonalized or assigned to another ("madame L."). The chaos and 
uncertainty of the first version are mitigated in the second through intellectual memory's influence, but this is not to say that they are entirely erased. Duras' use of a more literary tone in the second version certainly subdues the initial anguish present in the first, but this tone also creates a clearer, more recognizable description of the emotions linked to the events she describes. The result is a narrative of an emotional state that is more easily interpreted by a larger audience, without ever fully allowing emotional accuracy to be subsumed by a need for historical accuracy. In the following chapter I will explore the psychoanalytic significance of trauma so that we may arrive at a better understanding of the reasons for the tension between deep memory and intellectual memory present in "La douleur." By studying the recurrence of the traumatic event as a contemporary experience, and the difficulty of consciously and retroactively witnessing this material two key mechanisms of trauma - we will see how a path emerges from the anguish of not knowing to the reassuring sense of self achieved through acceptance and closure. This path is present both within the individual versions of "La douleur" and between the two. 


\section{Chapter II}

\section{Narrating Trauma: Mastering the Unknown}

The excerpts that I have just considered demonstrate a conspicuous change in tone, shifting from a narrative that strives to capture the initial uncertainty of trauma to one which is better able to reconcile this uncertainty and discuss it in more concise terms. However, I do not wish to suggest that the original diary is articulated only through the voice of deep memory, nor that the rewritten version is derived purely from intellectualized memory. In each version of the narrative there is a back and forth between these two modes of remembering that underscores just how ineffable trauma can be. While certain impressions and feelings resulting from the traumatic event can be better contextualized with the passage of time, others may forever resist such comprehension. It is the trauma survivor's ability to integrate these two types of memory and to understand the underlying significance of each that allows for a sense of closure to be reached. The purpose of remembering and narrating trauma, of bearing witness to it, is not to establish an authoritative account of events as corroborated by History, but to find a way to cobble together the fragmented memories of a traumatic experience into a continuous narrative that can be placed within the larger context of one's own personal history.

The purpose of this second chapter is to outline a psychoanalytic understanding of trauma - its origins, its symptoms, and its resolution - so that we may develop a stronger appreciation of the psychological significance of the dueling narrative tones in the original diary and "La douleur." As in the first chapter, I will structure this portion of my 
investigation around the study of certain episodes that appear in both versions of the narrative. However, while the excerpts that I previously discussed reveal a shift toward understanding and depersonalization, the focus of this chapter will be to examine moments in the text - particularly the rewritten version - that seemingly resist this reassuring effect. If we conceive of bearing witness to trauma as a process of reexternalization and reintegration, then the narrating Duras' occasional refusal to defer to intellectualized memory would seem to suggest an inability and/or unwillingness to minimize and let go of her initial raw impressions. Referring to studies by Sigmund Freud and Pierre Janet - which, though dated in some ways, are still relevant when discussing trauma and closure - as well as the work of Jacques Lacan, I will consider the relationship between the stages of trauma and how these stages are reflected and articulated in the text. I will also refer to Duras' screenplay for the 1959 film Hiroshima Mon Amour, which explores similar themes of remembering and forgetting. Doing so will reinforce my contention that neither the original diary nor "La douleur" need be completely historically accurate in order for them to present a convincing, emotionally accurate portrayal of trauma as Duras experienced it.

In both the original diary and the rewritten version, the narrating Duras is haunted by recurrent visions that attempt to locate Robert and explain his absence. These passages are devoid of hindsight, even in their rewritten form, as if something about this experience prevents it from being completely rationalized. These episodes feature a singular narrating self: Duras in present 1945. This narrating self never defers, if even momentarily, to her historically informed, intellectualized version of memory, rather she 
is entirely in the moment of the event at the time of the writing in 1945 as well as in 1985. The sudden absence of information heightens the feeling of uncertainty Duras describes during her wait for Robert, while the accumulation of these scenes evokes the underlying mechanism of trauma at work. As both versions of "La douleur" begin, the narrating Duras describes Robert's imagined return:

Il pourrait revenir directement, il sonnerait à la porte d'entrée : «Qui est là? » «C'est moi. » Il pourrait également téléphoner dès son arrivée dans un centre de transit : «Je suis revenu, je suis à Lutétia pour les formalités." Il n'y aurait pas de signe précurseur. Il téléphonerait dès son arrivée. Ce sont des choses qui sont possibles. Il en revient tout de même. Il n'est pas un cas particulier ... $(C G 175)^{12}$

Despite the use of the French conditionnel, which suggests the probability of a future event but not certainty, the narrating Duras' precise description of Robert's return in this excerpt points to a conscious attempt to believe that his return is not a mere possibility, it is assured. Though this conviction is, in present 1945, based only on speculation, it demonstrates an instinctive impulse to understand and contextualize Robert's absence. Imagining his return in such vivid detail temporarily alleviates the agonizing uncertainty of waiting. It is as if by envisioning this return the narrating Duras fortifies her already wavering conviction that Robert will return and momentarily frees herself from the maddening pain of not knowing. Yet the increasing prominence in both narratives of a contrasting scene that imagines Robert's death shows to what extent his absence remains

${ }^{12}$ I have chosen to include the version of this episode that appears in original diary contained in Cahiers de la Guerre. However, the version that appears in La Douleur is nearly exactly the same, save for a few differences in punctuation, the word "avant coureurs" instead of "précurseur" and "Il téléphonerait. Il arriverait," in the place of "Il téléphonerait dès son arrivée." Also in this version the Lutétia is referred to as "l'hôtel Lutetia" (without the accent). This episode appears on page 13 of La Douleur. 
unaccepted. In the original diary Duras describes her sudden paralyzing certainty that her husband has been dead for weeks:

Je reste immobile, le front contre le fourneau. Silence. D., dans l'appartement, ne fait aucun bruit. La rumeur du gaz, c'est tout. Où ? Où est-il ? Où se trouve-t-il ? Mais où nom de Dieu, où? Le fossé noir - mort depuis quinze jours. Sa bouche est entrouverte. Sur la route, à son côté, passent les armées alliées qui avancent sur tous les fronts. Mort depuis quinze jours. Depuis quinze nuits, quinze jours, à l'abandon dans un fossé, la plante des pieds à l'air. Sur lui, la pluie, le soleil, la poussière des armées victorieuses. Depuis quinze jours. Ses mains ouvertes. Chacune de ses mains plus chères que ma vie. Connues de moi. Connues de cette façon que de moi. ( $C G 181)$

Despite being a pure figment of the narrator's imagination, as she could hardly have known precisely what her husband experienced in the camps, this vision of Robert's death is described with the same precision and composure that she uses to describe her own location and actions. Robert's death, his abandoned body, and the sun and rain that beat down on it are as real and as definite as her own corporeal self as she rests against the kitchen stove. This vision, and later the memory of this vision does not bear the mark of informed memory, for there is no interruption by a post-1945 narrating Duras that reminds us that this was only a hallucination. Nor does such an indication appear in the corresponding version of this episode from 1985:

Je reste là. J'appuie mon front contre le rebord de la table, je ferme les yeux. D. dans l'appartement ne fait aucun bruit, il y a seulement la rumeur du gaz. On dirait le milieu de la nuit. L'évidence fond sur moi, d'un seul coup, l'information : il est mort depuis quinze jours. Depuis quinze nuits, depuis quinze jours, à l'abandon dans un fossé. La plante de pieds à l'air. Sur lui la pluie, le soleil, la poussière des armées victorieuses. Ses mains sont ouvertes. Chacune de ses mains plus chère que ma vie. Connues de moi. Connues de cette façon-là que de moi. ( $L D 19)$ 
Though this version of events may appear more refined through its use of metaphor ("L'évidence fond sur moi”) and insight (“On dirait le milieu de la nuit"), it retains all the panicked certainty of the first while avoiding any acknowledgement of Robert's actual eventual return and survival. The certainty with which his death is depicted, in both versions, mimics the same kind of intellectualized precision that is present elsewhere in the 1985 narrative: dead for two weeks, his body lies in an indistinct ditch, the soles of his feet exposed and his hands half-open.

These visions, which appear and reappear without formal conclusion, recall the obstinate presence of fragmented traumatic memory as if the narrator were innately compelled to witness the unsubstantiated scene of her husband's death years later. Their inclusion in both the original diary and the rewritten version suggest a temporary ignorance, perhaps even refusal, of the historical facts available to Duras when she was rewriting "La douleur." The opportunity for present-tense mitigation of past anguish is thus prevented, despite the pain and confusion that arise as a result. These episodes attest to the persistently disruptive nature of unnamed trauma, and the subsequent desire to integrate trauma into one's personal history so that the unsettling event can be witnessed and narratized. The visions of Robert's death in both versions of the text are therefore emblematic of Duras' early attempts to rationalize Robert's absence, to know her trauma. By including these episodes in both versions of the text - without recourse to further intellectualization - Duras renders her depiction of trauma all the more accurate through her illustration of the oppressive quality trauma assumes before it is fully understood and contextualized. When the fragmented memories surrounding a traumatic experience (real 
or imagined) are selected, ordered, and named, they become anchored in time and space, allowing them to be witnessed and accepted as belonging to the past, re-externalized and reintegrated. Narratizing the traumatic experience, including the recurring visions that occur in its wake, allows the trauma survivor to drain the traumatic experience of its omnipresence, thereby reclaiming her sense of agency.

To begin to address the necessity of narrating and its role in reintegrating the self after a traumatic experience, it is worthwhile to first examine trauma as it was initially explained by early psychoanalytic theory. As first discussed by Freud in Beyond the Pleasure Principle, trauma occurs as "a consequence of an extensive breach being made in the protective shield against stimuli" (38). This "shield" refers to one's level of preparedness for a particular event, be it pleasurable or troublesome, and indeed, Freud observes that the cornerstone of all trauma rests on the element of surprise and fright that is felt in conjunction with an unwanted experience (10). Yet Freud is also careful to note that while 'fear' and 'fright' may be cause for trauma, these terms are not to be used synonymously with 'anxiety,' which has the opposite effect. Developing anxiety, Freud suggests, allows the conscious self to expect and prepare for potentially dangerous and unpleasant experiences. Following this logic, it is the presence of anxiety that strengthens the figurative barrier existing between the mind's assured understanding of time, place, and self and the uncomfortable experience that threatens to disrupt this understanding.

In the absence of such preparation, what is unpleasant and therefore unwanted is experienced too abruptly, too unexpectedly, to be fully consciously perceived and understood (that is, mentally organized into a coherent narrative), and it is this absence of 
recognition from which trauma is born. As the traumatic experience cannot be fully assimilated into the ongoing conscious narrative that represents one's own personal history, the imprint that it leaves behind, the traumatic memory, exists in an inchoate, repressed state, ensconced within the subconscious, beyond the reach of conscious perception. The repression of such undesirable experiences is a mechanism of trauma motivated primarily by the hesitancy to acknowledge the event, as if refusing to testify to it erases the actuality of its happening. Before its conscious realization, traumatic memory resides in the unconscious; its significance is buried in the gap between what is experienced and what can be recounted (Lacan 35). In this state traumatic memory cannot be fully accessed, its significance remains unrealized and resists being misconstrued through language. In other words, meaning is (re)created through order, giving significance to the traumatic event. If trauma is chaos, then the ordered language through which trauma is narrated can help to tame it and make sense of it - although this is easier said than done. Repression serves as a means by which trauma's rationalization and inclusion within a personal chronology is prevented, and it is the absence of this historicization, Freud observes, that ultimately distinguishes all conscious thought from the unconscious:

As a result of certain psycho-analytic discoveries, we are today in a position to embark on a discussion of the Kantian theorem that time and space are 'necessary forms of thought.' We have learnt that unconscious mental processes are in themselves 'timeless'. This means in the first place that they are not ordered in time, that time does not change them in any way and that the idea of time cannot be applied to them. (Freud 33, emphasis mine) 
This absence of time recalls the kind of sensory memory discussed in the previous chapter, for deep memory, too, represents a mode of remembering that strives to recall the past self as though it were in an enduring present, never fully committed to an organized and determined past through the regimented system of linear language.

Trauma can therefore be thought of as the presence of an absence: an absence of time, of chronology, of full understanding and personal significance - all of which prevent the traumatic experience from being remembered as an event belonging to the past. Instead this repressed, unrealized material is repeated as a contemporary experience (Freud 19), and it is this point that is reflected in Duras' inclusion of her recurrent imagined witnessing of her husband's death in both versions of "La douleur." By continually bearing witness to Robert's death, and doing so in the present 1945 without deferring to a more intellectualized, historically informed mode of remembering, the narrating Duras demonstrates how this compulsion to repeat manifests in her daily life, as each time she "witnesses" Robert's death the circumstances are identical. What occurs again and again in these scenes is her attempt to fully recognize that which resists total comprehension: the circumstances surrounding Robert's disappearance and prolonged absence. Although Duras is able to come to terms with certain aspects of the Occupation, as we have seen through her shortened, reordered, and informed narrative in the 1985 version, her struggle to understand Robert's disappearance is not so easily remedied. Having been absent from the meeting at which Robert and his comrades were apprehended, Duras quite literally "missed" the moment of his disappearance - a disappearance which, for her, becomes synonymous with death. By repeatedly 
"witnessing" her husband's death, the narrating Duras is forced to confront what she fears most. As she relates the content of these visions in the text, we see her trying to create her own logical explanation for Robert's absence. The imagined scene of his death is a narrative metonymy: Duras replaces a traumatic event that she cannot witness (her husband's disappearance and continued absence) with one that she invents and can thus narrate in an attempt to understand and no longer suffer from his absence. The personal narrative she creates contextualizes and rationalizes, locating Robert in time and space and affirming the circumstances of his death:

Dans un fossé, la tête tournée vers la terre, les jambes repliées, les bras étendus, il se meurt. Je vois. Tout. Il est mort de faim. À travers les squelettes de Buchenwald, son squelette. Il fait chaud. Peut-être commence-t-il à pourrir. Sur la route à côté passent les armées alliées qui avancent sur tous les fronts. Il est mort depuis trois semaines. Ça y est. Je tiens une certitude. Les jambes continuent à marcher. Plus vite. Sa bouche est entrouverte. C'est le soir. Il a pensé à moi avant de mourir. (CG 178)

[Dans un fossé, la tête tournée contre la terre, les jambes repliées, les bras étendus, il se meurt. Il est mort. À travers les squelettes de Buchenwald, le sien. Il fait chaud dans toute l'Europe. Sur la route, à côté de lui, passent les armées alliées qui avancent. Il est mort depuis trois semaines. C'est ça, c'est ça qui est arrivé. Je tiens une certitude. Je marche plus vite. Sa bouche est entrouverte. C'est le soir. Il a pensé à moi avant de mourir. ( $L D$ 16)]

As in the hallucination experienced in the narrating Duras' kitchen, discussed earlier in this chapter, Robert is seen in a mass grave, limbs bent, dead for weeks. Again, the narrating Duras experiences these scenes with unwavering certainty, assured of the time and cause of his death, thus restoring a precise chronology to his (assumed) death an event that previously transcended such organization. Phrases like "Je tiens une certitude" and "C'est ça" suggest a craving for certainty, a desire to no longer wonder. It 
is as though by continually returning to this scene $(C G 178,181,216 ; L D 16,19)$ and affirming its accuracy the narrating Duras can retroactively prepare for Robert's death by exercising a newfound control and mastery over what remains uncertain and strengthening the figurative shield that exists between her intact conscious self and the unwelcome event. Not having witnessed Robert's arrest or deportation (or death, for that matter), these events exist outside of what Dori Laub describes as "the parameters of normal reality," giving them a certain salience and timeliness outside the range of recognition and mastery that prevent the trauma survivor from accessing the "core of his traumatic reality" (69). To reverse the subsequent feelings of entrapment that stem from this lack of access, a process of narratization, that is, "a process of constructing a narrative, of reconstructing a history and essentially, of re-externalizing the event" (69) must materialize. The scenes of Robert's death can be thought of not only as proof that Duras was haunted by his absence, but as an early attempt to narrate and explain his traumatic absence. This recalls Freud's observation that trauma, in its unconscious state, is beyond time and language. Narratizing the event reinscribes it within these boundaries. Laub continues:

This re-externalization of the event can occur and take effect only when one can articulate and transmit the story, literally transfer it to another outside oneself and then take it back again, inside. Telling thus entails a reassertion of the hegemony of reality and a re-externalization of the evil that affected and contaminated the trauma victim. (69)

The author-narrator's refusal of the historical record and her continual return to the scene of Robert's death, which she can never adequately witness, reveals to what extent Robert's sudden disappearance was, and may be still, a source of suffering. 
Including these episodes in both versions of "La douleur" without altering their tone demonstrates the narrating Duras' ongoing attempt to appropriately contextualize and recount the many facets of a traumatic experience. Excluding from the rewritten diary the information that would otherwise resolve Robert's absence underscores to what extent his disappearance defied explanation, thereby preserving the emotional accuracy of the original diary. To be emotionally accurate and faithful to the lived experience, these episodes must be included because they illustrate how Duras' need and struggle to interpret and understand her trauma is present from the very beginning.

Preserving these hallucinations as they were experienced, without the soothing benefit of hindsight, better captures the persistent nature of these visions as early attempts at mastering the unknown. Yet it should come as no surprise that despite their recurrence and the certainty with which they are described, these hallucinations do not adequately produce the desired sense of closure that should result from re-externalization, and this too is reflected in the narrating Duras' descriptions of these visions:

Un autre enchaînement (mon enchaînement, je suis enchaînée) me tient : peut-être est-il mort depuis quinze jours, dans ce fossé, les bêtes lui courent déjà dessus, il est mort sans avoir mangé un morceau de pain, balle dans la nuque ? balle dans le coeur? rafales dans les yeux ? sa bouche blême contre terre allemande, et moi j'attends toujours parce que ce n'est pas sûr, il vit peut-être encore, d'une seconde à l'autre il va peutêtre mourir, seconde par seconde, toutes les chances se perdent et se retrouvent, peut-être est-il dans la colonne, pas à pas il avance, courbé, si fatigué qu'il ne va peut-être pas faire le prochain pas, qu'il s'est arrêté, y a-t-il de cela quinze jours ? six mois ? tout à l'heure ? il y a une seconde ? dans la seconde qui suit ?" (CG 216)

[Un autre enchaînement nous tient : celui qui relie leur corps à notre vie. Peut-être est-il mort depuis quinze jours déjà, paisible, allongé dans ce fossé noir. Déjà les bêtes lui courent dessus, l'habitent. Une balle dans la 
nuque ? dans le coeur? dans les yeux ? Sa bouche blême contre la terre allemande, et moi qui attends toujours parce que ce n'est pas tout à fait sûr, qu'il y en a peut-être pour une seconde encore. Parce que d'une seconde à l'autre seconde il va peut-être mourir, mais que ce n'est pas encore fait. Ainsi seconde après seconde la vie nous quitte nous aussi, toutes les chances se perdent, et aussi bien la vie nous revient, toutes les chances se retrouvent. Peut-être est-il dans la colonne, peut-être avance-til courbé, pas à pas, peut-être qu'il ne va pas faire le second pas tellement il est fatigué? Peut-être que ce prochain pas, il n'a pas pu le faire il y a de cela quinze jours? Six mois? Une heure? Une seconde? (LD 47)]

In this instance the narrating Duras is less certain of the cause of Robert's death, as she cannot discern whether he starved or whether - and where - he was shot. In fact, she is even less sure that he is dead at all, as indicated by her inability to specify when exactly he died. He may still be marching, evading death with every second that passes. However, what is accurately reflected in this episode is the narrating Duras' assertion that she is chained to this uncertainty, an assertion which attests both to her recurring imagined witnessing of Robert's death - what we might call a crisis of death - as well as the ongoing difficulty of living with such oppressive uncertainty - a crisis of survival. Though the rewritten version of this episode tends toward intellectualization in Dura's meditation on the cycle of life ("Ainsi seconde après seconde la vie nous quitte nous aussi...”), such an observation can also be understood as a clearer articulation of its previous equivalent ("seconde par seconde, toutes les chances se perdent et se retrouvent"). This reformulated observation does not diminish the excruciating certainty/uncertainty conveyed in this excerpt, but clarifies its meaning, sharpening its impact.

Because Duras, in both 1945 and 1985, can never truly know, see, or experience in the first-person what befell Robert during his time as a prisoner, she can likewise never 
fully contextualize the whole of her traumatic experience. Her inability to witness her husband's disappearance and following absence is therefore the mainspring of trauma at the heart of "La douleur." From this perspective, Duras' imagining of Robert's death allows her to narratively 'approach' - attempt to name - the traumatic event of his disappearance. Furthermore, because Robert's return and survival do not undo this inability to truly witness, the trauma remains current, further explaining the absence of total intellectualization - the ability to explain away these visions as pure illusion - in the rewritten version. It is this dual nature of trauma that leads Caruth to ask: "Is the trauma the encounter with death, or the ongoing experience of having survived it?" (7), and makes a clearer case for the need to revisit and reformulate the contents of the original diary, a need which I will explore in more detail in the following chapter. Caruth's question invokes the paradoxical nature of traumatic experience, as the intrusive and repetitive hallucinations that accompany trauma belatedly attempt to name what can never be fully known. The desire and need to narrate trauma is complicated by the inability to know it completely, and this paradox is best illustrated through Lacan's interpretation of the story of the burning child, first described by Freud.

In The Interpretation of Dreams, Freud introduces the story of a father whose child, after a prolonged illness, finally succumbs to his fever and dies. The father, seeking a moment of rest after tending to his sick child, leaves his child's body under the supervision of an older man, and goes into the adjoining room where he soon falls asleep. The father then has a dream in which his child appears to him, takes him by the arm and asks reproachfully, "Father, can't you see that I am burning?" The father awakes to see 
that a candle has fallen in his child's room, setting the sheets and one of the child's arms on fire (330). Freud initially posited that this dream represented a moment of wishfulfillment for the father: that by sleeping one moment longer the father was able to once again see his child alive (331). It is as though the father is unable to confront the reality of his child's death in his waking life, and so can only experience it through a dream. However, as Freud continues to explore the nature of dreams in this chapter his explanation of this dream and the more general desire to sleep as a simple opportunity for wish-fulfillment no longer suffices. Instead the dream comes to represent only one aspect of the conscious desire to sleep, which is, paradoxically, the conscious desire to withdraw from consciousness. The father's dream prolongs his sleep not only because he wishes to see his living child one moment longer, but because there exists an overriding conscious desire to retreat from reality. Therefore, Freud notes, "throughout the entire state of sleep, we know just as certainly that we are dreaming as we know that we are asleep" (374). This naturally raises the question: what does it mean to want to remain asleep? There is likely a parallel to be drawn here between the desire to continue to sleep and the repressed.

When Lacan returned to this story in his seminar "Tuché and Automaton" he saw in it another question, a corollary to the one mentioned above: if dreams are the result of the conscious desire to withdraw, what does it mean to awaken? (58). The words that wake the father - "Father, can't you see that I am burning" - come not from outside, but from within the dream, the very dream which is meant to prolong sleep. Awaking from this dream, leaving one reality for another, is what enables the father's true encounter 
with his child's death, for it is in response to the dreamed plea for help that the father awakes to the reality of this death. The father's desire to respond to his child's words and save him is inarguably futile: as he awakes, he realizes once again that he is too late, his child is already dead. Through his dream, the father re-enacts his inability to save his child, his inability to encounter and triumph over death. The burning child in the father's dream therefore embodies the compulsion to repeat described by Freud in Beyond the Pleasure Principle (Freud 25).

If the dream of the burning child re-enacts the encounter with the child's death, then awaking from this dream reaffirms the reality of this death and, at the same time, reaffirms the father's survival. For this reason, Lacan's interpretation of the dream reveals that the father and child are "inextricably bound together through the story of a trauma" (Caruth 102), as the father's identity as a surviving parent can only be defined in its opposition to the dead child. It is only in his waking, conscious state that the father can begin to comprehend the reality of his child's death. This conscious recognition thus requires that the father dissociate himself from the traumatic death of his child and reclaim his autonomy, freeing himself from the vexing grasp of unreconciled trauma, illustrating the vital role of a reintegrated self in the search for closure. Asleep, the father cannot master the reality of his child's death and by extension cannot distinguish between this death and his own survival. It is only through waking that this distinction can be made and the father may begin to speak of this trauma.

Again we arrive at the unsettling paradox inherently tied to witnessing: only through conscious separation from traumatic memory can one begin to find closure. I 
have used the terms 'dissociation' and 're-externalization' interchangeably to refer to this separation as I find both terms to be equally evocative of the material act of narrating. Transferring the sensory quality of traumatic memory into shared, spoken and written language renders the traumatic event both recognizable, in the sense that it can finally be witnessed, and unrecognizable, to the extent that language inevitably betrays the totality of the event in question. Traumatic narratives therefore bear witness to what can be remembered and also, implicitly, to what has been and must remain forgotten. This is what occurs in Duras' texts: by writing and rewriting her account of a traumatic experience, she attempts to exert an increasing level of control over these events and "awakes" to the reality that she exists and has not, in fact, come undone as a result of Robert's disappearance. Her visions of Robert's death, like the dream of the burning child, do not adequately explain or allow Duras to master his traumatic absence. But by including these episodes in the narrative, and bearing witness to the anguish they caused, the narrating Duras can face them and include them as an integral part of her path toward closure, a journey that implicitly reaffirms her status as a survivor of trauma.

It is thus through the narration of her visions of Robert that we can perceive her struggle to awaken to the reality of her own survival and to reassert her autonomy as a self-possessed survivor of a traumatic experience. Understanding Robert's absence as part of a larger historical context allows the narrating Duras to assign, at least temporarily, significance to his traumatic absence. Intellectualizing this absence - he is being held at the Lutetia for formalities with other deportees ( $L D 13, C G 175)$, or he is already dead in a German concentration camp ( $L D 19, C G 178,181,216)$ - reveals itself 
to be a mechanism of survival. Like the father in the story of the burning child, Duras

cannot remain 'asleep' forever. She must accept Robert's disappearance and re-establish

her autonomy. As she repeatedly tries to encounter either Robert's survival or his death,

she inevitably awakens to the fact that she is still alive:

Il est possible qu'il revienne ... Ils ont fini par franchir le Rhin. La charnière d'Avranches a fini par sauter. J'ai fini par vivre jusqu'à la fin de la guerre. (CG 175)

[Il est possible qu'il revienne ... Ils ont fini par franchir le Rhin. La charnière d'Avranches a fini par sauter. Ils ont fini par reculer. J'ai fini par vivre jusqu'à la fin de la guerre. ( $L D 13)]$

À côté du fossé, le parapet du pont des Arts. La Seine. Exactement à droite du fossé. Quelque chose les sépare : du noir. Le pont des Arts. Ma victoire. Rien au monde ne m'appartient que ce cadavre dans un fossé. L'enfance a été. L'innocence a été. C'est le soir. C'est ma fin du monde. J'emmerde tout le monde. Je ne meurs contre personne. Simplicité de ma mort. J'aurai vécu ... (CG 179)

[À côté du fossé, le parapet du pont des Arts, la Seine. Exactement, c'est à droite du fossé. Le noir les sépare. Rien au monde ne m'appartient plus, que ce cadavre dans un fossé. Le soir reste rouge. C'est la fin du monde. Je ne meurs contre personne. Simplicité de cette mort. J'aurai vécu. ( $L D$ 17)]

However, the recurrent nature of these episodes in both texts suggest that Duras' narrating self is not yet convinced that she will have outlived Robert. She makes several attempts to intellectualize his absence, as though attempting to delineate between her life and his death, which should then allow her to move toward a sense of acceptance and closure. But in obsessing over the event of his death, this narrating Duras ultimately allows her concept of Robert to hover in limbo, delaying the reintegration of the self that is necessary for witnessing and overcoming trauma.

The film Hiroshima Mon Amour, written by Duras and directed by Alain Resnais and released nearly halfway between 1945 and 1985, offers a unique approach to 
forgetting and narrating a post-war setting through the medium of film. Here, too, the characters in the scenario reflect upon the difficulty of telling a traumatic experience. Released in 1959, Hiroshima Mon Amour tells the story of a Japanese man and a French woman - referred to only as 'Il' and 'Elle' - during their last days together after a romantic encounter in Hiroshima during the summer of 1957. Through a series of conversations with the Japanese lover, the woman finally transmits the story of her own traumatic past: the death of her lover, a German soldier, at Nevers on the day of liberation, and her subsequent punishment and madness. Though it is through speaking to the Japanese man that she is finally able to transfer the story of this past trauma, in doing so she is forced to confront the inevitable betrayal of her personal past that occurs when her sensory memories are manipulated through spoken language

Though the liberation of Nevers should signal a long awaited freedom from the German Occupation, for the woman this day ironically marks the beginning of a period of entrapment. Having planned to leave Nevers with her German lover, the woman goes to meet him on the quays of the Loire. When she arrives, he has already been shot, but is not yet dead. The woman stays with his dying body all day and all night, slowly losing her ability to distinguish between her life and his death:

Ah! Qu'est-ce qu'il a été long à mourir. Quand? Je ne sais plus au juste. J'étais couchée sur lui... oui... le moment de sa mort m'a échappé vraiment puisque... puisque même à ce moment-là, et même après, oui, même après, je peux dire que je n'arrivais pas à trouver la moindre différence entre ce corps mort et le mien... Je ne pouvais trouver entre ce corps et le mien que des ressemblances... (100)

The woman from Nevers missed the moment of the German lover's death in the same way that Duras missed Robert's arrest, deportation and possible death. The narrating 
Duras' continued efforts to rationalize Robert's absence (with little success) demonstrates that she is not prepared to accept the possibility of outliving Robert, a reluctance that is echoed in the woman's inability to find "la moindre différence" between her body and that of her dying lover. Instead, both Duras and the woman from Nevers experience a sort of fusion with the traumatic event: neither woman can accept the death of her beloved; they cannot recognize that they live while he dies, and as such neither can relegate Robert's/the German's death to the past.

Disgraced by her love affair with the German soldier, the woman from Nevers has her head shaved and is imprisoned in the cellar of her parents' home; her parents claim she is dead, preferring this illusion to the reality of her transgression (HMA 89). This forced entry into the cellar signals the beginning of a period during which the woman's conscious self is in a perpetually fragmented state, clinging desperately to the memory of her German lover (Caruth 31). As her perception of time and space is disrupted (she is unable to recall for how long she was kept in the cellar), so too is her perception of her corporeal self, as seen in her perceived separation of her hands from the rest of her body: "Les mains deviennent inutiles dans les caves. Elles grattent. Elles s'écorchent aux murs... à se faire saigner... c'est tout ce qu'on peut trouver à faire pour se faire du bien... et aussi pour se rappeler... J'aimais le sang depuis que j'avais goûté au tien" (HMA 89). Deprived of sight and understanding, the woman communes with her lover's death through the sucking of her own blood, and in so doing she becomes a living monument to his death (Caruth 31). 
In his study of the treatment of trauma, Pierre Janet, who like Freud was a pioneer in the field of psychoanalysis in the late nineteenth and early twentieth century, argues that forgetting is a necessary function of understanding. "To forget the past is, in reality, to change one's behaviour in the present" (680), he writes, referring to the modifying of traumatic memory, which in Janet's view is an integral step in healing the "fixed idea" of a traumatic experience (676). We may for our purposes understand this "fixed idea" to represent a lack of certainty regarding the traumatic experience itself - the persistence of visceral memory without a clear understanding of its significance. Indeed, when Janet cites one such instance in which it was necessary to suppress a fixed idea of trauma, he notes that what needed to be suppressed was, "the sound of the tolling bell, the sight of the corpses, the smell of these [corpses]" (676). In other words, the sensory quality of traumatic memory must be quieted before it can be fully understood. Unintellectualized memories such as these are developed "in isolation, without control and without counterpoise," (674) suggesting in turn that reintegrating these memories into the conscious narrative that is personal history produces their healing significance. It therefore may be said that such healing cannot commence before certain details of the traumatic experience are forgotten. In this way, forgetting and narrating, the act by which trauma is re-externalized, once again prove to be inextricably linked.

Similarly, the woman's eventual reintegration of her corporeal self, signaled by her ability to see and remember, to recognize her affair with the German and his death as belonging to the past, heralds her subsequent exit from the cellar. Recognizing these events as belonging to the past marks a turning point in her understanding: "Je commence 
à voir. Je me souviens avoir déjà vu - avant - avant - pendant que nous nous aimions, pendant notre bonheur. Je me souviens. Je vois l'encre. Je vois le jour. Je vois ma vie. Ta mort. Ma vie qui continue. Ta mort qui continue" (HMA 98). Exiting the cellar also represents an exit from madness, as it is her acceptance of her lover's death - a figurative kind of seeing - that allows her to stop screaming, to stop searching for him. Her sane seeing and knowing issues from her gradual forgetting - her gradual conscious separation from the memory of his body. It is only by forgetting his referential specificity that she can begin to accept this traumatic event as being part of a clear and defined past (Caruth 32). Incidentally, this return to rationality and understanding also coincides with the bombing of Hiroshima: when the woman arrives in Paris after leaving Nevers, 'Hiroshima' is all over the newspapers. In this way, her recovered sight and understanding are inscribed within a larger history that, as in "La douleur," contextualizes the traumatic event but does not demand that traumatic memory adhere perfectly to the historical record. This point is addressed from the very beginning of the film: in the opening scene we are confronted with images of a destroyed Hiroshima, scorched bodies, the hall of a hospital, and a museum juxtaposed with the repetition of the man's “Tu n'as rien vu à Hiroshima.” We are reminded that one can look at countless artifacts and remains of Hiroshima, read hundreds of books about war and bombings, but none of this will equal living through the event. The woman's freedom from madness, signaled by her ability to separate herself from trauma and speak of it, is thus, according to Caruth, a fundamental betrayal of the past (33), for as the woman begins to tell the story of her affair she realizes she is forgetting its specificity. The resulting narrative, delivered to the 
Japanese lover who assumes the role of the German soldier, testifies to her own traumatic past, as well as the impossibility of representing this past in a manner that is both faithful to the event and historically accurate. After finally telling the story of her past at Nevers to the Japanese lover, the woman addresses this conflict, as though speaking to her deceased lover: "J'ai raconté notre histoire. Je t'ai trompé ce soir avec cet inconnu. J'ai raconté notre histoire. Elle était, vois-tu, racontable" (HMA 110).

Returning to the process of forgetting and narrating present in "La douleur," we can now see the similarities between the woman from Nevers' path from madness to understanding and that of Duras' narrating self in both versions of "La douleur," despite the fact that the latter narrative does not always manage to accept and understand the trauma it recounts. Indeed, what drives both the first and second version of "La douleur" is the narrating Duras' struggle to make sense of, and quiet, the uncertainty that shrouds her understanding of her husband's sudden vanishing. As she clings to her memory of Robert, living or dead, the narrating Duras, like the woman from Nevers, is able to preserve the bodily referent of her trauma: Duras' narrating self confirms this integration on more than one occasion, remarking, "Sa mort est en moi" ( $L D$ 15) and "Rien au monde ne m'appartient plus, que ce cadavre dans un fossé” ( $L D$ 17).

It is only with Robert's return that the narrating Duras can separate herself from this bodily referent, as her corporeal self no longer needs to simultaneously function as a monument to his life. Seeing Robert alive (albeit teetering on the brink of death from starvation and typhus) allows Duras to finally see and understand that he has survived, and that she, too, has lived to see his return. As in Hiroshima Mon Amour, this return to 
understanding also signals the beginning of the process of forgetting, as the specificity of her anguish begins to recede into a finished and determined past. However, she is still unable to see and comprehend what truly befell him while he was away. Leaving her unsubstantiated visions of his corpse in both versions of the narrative affirms not only the existence of such haunting visions at the onset of trauma, but her continued struggle with the meaning of his absence as well. Some aspects of her traumatic past cannot be reconciled.

With the understanding that one need not possess the whole truth of her traumatic experience in order to bear witness to it, the accusations that "La douleur" does not accurately represent the past proffered by Duras' peers, such as Mitterrand and Mascolo, become superfluous truisms. While creating a narrative of trauma like "La douleur" does involve a reintegration of personal experience and personal history, this reintegration does not necessarily imply that the event itself must be completely eclipsed. Narratization of a traumatic experience does not require that personal memory cede entirely to a collective, historical record. Instead, meaning is created and understanding is achieved through the process of selecting, ordering, and contextualizing fragments of memory to create a cohesive narrative. What develops is a narrative that testifies not only to what is remembered, but also to what has been forgotten - that which cannot be recovered and cannot be witnessed.

The parallel dynamic existing between remembering/forgetting and historical/emotional accuracy that surfaces in the process of narratization was a point for discussion during a series of interviews between Duras and Mitterand organized by 
Michel Butel of the magazine L'Autre Journal. The first interview took place on July 24, 1985, shortly after La Douleur's publication, and Mitterrand did not hesitate to compare his version of Antelme's return to Paris to that of Duras' as portrayed in the second version of "La douleur." In Duras' version of events, she receives a phone call from Mitterrand telling her that Robert was discovered alive in Dachau and that Mascolo and Georges Beauchamp must leave right away with uniforms and false papers in order to infiltrate the camps that were then under allied supervision. Duras describes their return to Paris, having rescued Robert:

J'ai entendu des cris retenus dans l'escalier, un remue-ménage, un piétinement. Puis des claquements de portes et des cris. C'était ça. C'était eux qui revenaient d'Allemagne.

Je n'ai pas pu l'éviter. Je suis descendue pour me sauver dans la rue. Beauchamp et D. le soutenaient par les aisselles. Ils étaient arrêtés au palier du premier étage. Ils avait les yeux levés. $(L D 68)$

But Mitterrand corrects Duras, saying that her version of this event, in his estimation, is incorrect, reminding her that before giving the order for Beauchamp and Mascolo to leave for Germany he first returned to Paris, and that the group waited a night before departing for Germany. He then adds:

Quand ils sont arrivés à Paris, j'étais avec vous dans l'escalier de votre immeuble. On était assis sur des marches face à l'entrée. Quand vous avez vu apparaître le petit cortège qui le portait, toujours méconnaissable, vous n'avez pas bougé, vous étiez totalement pétrifiée... et puis vous vous êtes sauvée. (Duras and Mitterrand 21)

Mitterrand goes on to add that Duras perhaps did not portray the events within $L a$ Douleur as faithfully as she could have, commenting, with regard to "Monsieur X." (the second narrative in the collection), "Vous ne le racontez pas précisément dans le livre... 
Ça ne recoupait pas exactement mes souvenirs" (25). By this point in Duras' career it was certainly becoming more and more difficult to distinguish those times when she was merely obfuscating the truth in traditional Durassian fashion from those times when her memory simply failed; in fact, several pages after Mitterrand tells her he is not in complete agreement with her description of events in La Douleur, she asks, "Vous l'avez lu, mon livre?" (31).

Regardless of whose memory of Robert's return is historically correct, the discrepancy between the two accounts confirms not only the subjective nature of memory, but the integral role of forgetting in the narratization of traumatic memory. Duras is able to tell her story, but only by forgetting and confusing the details. Just as Robert's arrest and deportation occurred abruptly and unexpectedly, so too did his return - an event which, according to both Duras and Mitterrand, she literally tried to run away from. The description of his return therefore, like Duras' description of waiting for this return, indicates that certain details had to be relegated to the past and/or entirely forgotten before the entire event could be narratized. When Mitterrand shares his own memory of this return, Duras confirms, "J'avais oublié que vous étiez avec moi dans l'escalier. J'ai presque tout oublié de ce retour, sauf lui, Robert"'(21).

The material process of generating testimony now reveals itself to be a necessary but perpetually incomplete process. The impulse to construct a unified account of trauma from impressionistic memory is inevitably undermined by the impossibility of both remembering and knowing. If understanding is only achieved through forgetting, transferring amorphous memory into linear narrative language erases its specificity. 
However, with the reoccurring image of Robert's death, this same specificity is restored to the text by virtue of its resolute and unglossed tone. Each time that she communicates an image of Robert's corpse, the Duras who is both author and narrator recreates the invasive and incomprehensible quality of traumatic memory by indirectly testifying to its continuously inchoate perception. Leaving these excerpts in the rewritten text untouched additionally confirms that her journey to reintegrate this trauma is indeed an ongoing process, beginning only months after Robert's deportation and continuing even after she testifies to witnessing his return (which is described only near the end of the rewritten narrative). The dual narratives of "La douleur" thus create a dialogue between the narrating Duras of 1945 and the author-narrator Duras who revisits and attempts, with varying degrees of success, to modify the former's testimony, affirming that the process of re-externalization and reintegration - what we may call testifying - is indeed a dialogic one (Laub 70).

In his 1985 interview with Duras, Mitterrand seemed acutely aware of this notion when he observed: "Vous avez attendu quarante ans avant de publier un livre sur cette période. Enfin, vous l'aviez écrit avant, mais ce n'était pas un récit extériorisé, c'était vous avec vous-même, ce n'était pas vous et les autres" (Duras and Mitterand, 33). ${ }^{13}$ It is this idea of re-externalizing, of transmitting the memory of an event to a distinct other, that is central to narrating trauma, for in order for traumatic memory to be fully interpreted and dissociated it must not only be witnessed by the trauma survivor but

\footnotetext{
${ }^{13}$ Mitterrand is perhaps referring to the first version of "La douleur," as it appeared under the title "Pas mort en déportation," when he remarks that Duras had already written the story of her wait for Robert, and this version of the narrative is indeed far more fragmented and private than the version published in 1985, as I have previously noted.
} 
received (or able to be received) by an Other. Language, then, is what allows for such interpretation and transfer, condensing traumatic memory into a linear narrative that can be communicated and understood. Though both versions of "La douleur" contain an exteriorized, linguistic narrative of trauma, the rewritten copy is often more refined, as if intended specifically for a listener: the reader. In this light, the control exacted over the events described in the version of "La douleur" published in 1985 is not representative of a purposeful manipulation of the truth, but a desire to convey the personal and emotional memory of this period as accurately and concisely as possible. In the third chapter I will discuss how this dialogue manifests itself still further in "La douleur" when we consider that its narrative contents were written and then rewritten - witnessed and rewitnessed. 


\section{Chapter III}

\section{Writing Trauma: Accepting the Absence}

In the previous chapters I examined the ways in which the tone of Duras' original diary changed as it was rewritten for publication in 1985, and what these changes demonstrate in terms of processing trauma. The fact that neither the original diary nor the rewritten version are articulated entirely through the voice of deep memory or intellectual memory proves that Duras' recollection of the traumatic event in question (her husband's absence) is destined to be incomplete; some moments from this traumatic period remain too confounding to be organized into coherent narrative, while the rough edges of others are softened and minimized as they become exposed through language. This of course is the purpose of retelling a traumatic event: moving out from under the shadow of a memory and facing it, naming and accepting what cannot be named. A truly objective account of a traumatic event, retold entirely in line with a historical record, is an impossibility. As the earlier discussion of trauma's origins has shown, those who dismiss "La douleur" purely for its inaccuracies are misguided in their interpretation: inaccuracy is a fundamental part of narrating trauma.

To further support this view, in this chapter I will focus on the nature of writing and language - why they are able to provide solace, and how they transform the events they describe. Using the work of critics such as Jacques Derrida, Maurice Blanchot, and Roland Barthes, I will devote the first portion of this chapter to the establishment of two distinct entities of the mechanism of writing: the circumstances that necessitate its use 
and the absence that materializes. This will further prove that a uniformly objective account of trauma is impeded by writing's erasure of the singular idea it endeavors to communicate. In the second half of this chapter, I will consider how the diary form, which puts the reflexive act itself on display, balances this erasure and preserves the emotional accuracy of the experience recounted in both versions of the narrative. Finally, I will briefly examine the concept of autofiction and its status as a genre that directly confronts the inability to accurately and objectively translate the subjective perception of self and personal experience. This will show that the historical inaccuracies and stylistic differences between the original diary and "La douleur" serve as the foundation for a narrative that presents an emotionally accurate portrait of coming to terms with trauma.

I would like to take as a point of departure a loose definition of writing as offered by Derrida in "Signature Event Context":

If we take the notion of writing in its currently accepted sense - one which should not - and that is essential - be considered innocent, primitive, or natural, it can only be seen as a means of communication. Indeed, one is compelled to regard it as an especially potent means of communication, extending enormously, if not infinitely, the domain of oral or gestural communication. (3, original emphasis)

In this passage two traits are attributed to writing, the first of which links it to other forms of communication. Writing, like oral communication and gesture, is employed to transport a thought or idea - a "signified content" (4) - so that we may say what we mean and in turn have that meaning be understood. Though Derrida does acknowledge that communication is polysemic (3) and not confined exclusively to linguistic representation, he suggests that writing in particular distinguishes itself from other forms of 
communication by its ability to extend beyond the presence of its author, and this is the second trait, which is unique to writing. 'Extend' or 'extension' can mean two things when used to describe writing. First, that writing expands the possibility for communication beyond oral, gestural, or any other kind of communication, and second, that writing is a durable form of communication that extends beyond the presence of its author and reaches a recipient who was absent at the time of writing. Unlike oral communication, which implies the presence of a speaker concomitant with the act of speaking, writing implies a delay between the production of content and its reception. It functions in the "radical absence of every empirically determined receiver in general" (8). Regardless of his or her exact identity, writing always assumes an addressee.

These characteristics are applicable to all writing, but of particular interest here are their implications in literary writing, or the creation of literature. If, as a form of communication, writing ascribes significance to an unrealized intention - the idea or plan of what must be communicated - by transporting it into the realm of shared language, then it may be said that a text and its narrative contents cannot be fully grasped or understood (by writer or recipient) until it is written. In her essay "Écrire" published near the end of her life, Duras addresses this same impossibility of determining a text's identity before it is completed, observing rather insightfully, "L'écriture c'est l'inconnu. Avant d'écrire on ne sait rien de ce qu'on va écrire" (64). The inability to truly "know" a text before it is written should call to mind a similarly enigmatic pursuit: witnessing trauma and narratizing the event. The trauma survivor absents herself from the moment of the traumatic event (in this case Robert's arrest and deportation) and can only begin to 
understand the significance of his or her residual impressions by re-externalizing them through language; testimony can only be grasped "in the movement of its own production" (Felman 16). In much the same way, the text emerges from a previously ineffable idea and assumes its identity only once it is written; before this it is nothing (Blanchot, "Littérature" 297). Implicit in both witnessing and writing then is the juxtaposition of a visceral impression and the ability to communicate it. Like trauma, which gradually loses its referential specificity as subjective impression is molded into organized and transferable testimony, writing also erases the singularity of the author's original intent for a text.

Here we encounter the paradox that I described earlier in this chapter: writing, and language in general, function as a tool for generating meaning and understanding, but they are only able to do so by replacing/erasing the singular idea that they are meant to express. Blanchot defines language as "l'état de la parole commune telle qu'elle est donnée à chacun de nous ensemble, à un certain moment du temps et selon notre appartenance à certains lieux du monde ; écrivains et non-écrivains l'ont également en partage" ("Recherche" 250). Several words in this definition underscore the removal of inward feeling from language: commune, nous ensemble, appartenance, partage. Language is shared; it belongs to a people and in turn allows the individual to belong. Language makes the unknown familiar, and through it one is able to gain control over his or her surroundings (Blanchot, "Littérature" 312).

However, in exchange for this familiarity, this ability to understand and be understood, the author's intention is obscured, perhaps even sacrificed. This push and 
pull between the personal and the common (author and readers), the specific and the general, prove to be of central importance in writing, and this tension is very much put on display in the original and rewritten versions of "La douleur." The original diary presents itself as a private document; its lack of determiners, traditional syntax, and linearity suggest that this text is not meant to be shared or understood by others and records in the moment the impressionistic quality of trauma that remains internalized. Conversely, the rewritten version aims to intellectualize and minimize the trauma of the first, transforming it into a streamlined narrative, intended to be shared with and understood by others:

Si je suis lâche, je le sais ; ma lâcheté est telle qu'on n'ose pas la qualifier autour de moi. Mes camarades de service me parlent comme à une malade. M. et A. aussi. Moi, je sais que je ne suis pas malade. Je suis lâche. D. me le dit quelquefois : «En aucun cas, aucun, on n'a le droit de s'abolir à ce point. » Il me le dit souvent : «Vous êtes une malade, vous êtes une folle. "Lorsque D. me dit aussi : "Regardez vous, vous ne ressemblez plus à rien », je n'arrive pas à saisir. (CG 193)

Ma lâcheté est telle qu'on ne la qualifie plus, sauf D. Mes camarades du Service des Recherches me considèrent comme une malade. D. me dit : « En aucun cas on a le droit de s'abolir à ce point. » Il me le dit souvent : «Vous êtes une malade. Vous êtes une folle. Regardez-vous, vous ne ressemblez plus à rien. » Je n'arrive pas à saisir ce qu'on veut me dire. [même maintenant quand je retranscris ces choses de ma jeunesse, je ne saisis pas le sens de ces phrases.] ( $L D$ 33)

Though it is not my intent here to embark on a lengthy discussion of semiotics, in order to understand the dissociative power of language when narrating and writing trauma it is necessary to give a brief definition of 'the sign' - the basic unit of language. A sign comprises both the "image" or "physical imprint of a material phenomenon- the signifier - and the concept or ideal meaning - the signified (Derrida, "Différance" 10). 
When, for example, Duras writes the word journal she conjures up the image of a text along with the concept of an object in which one records his or her daily thoughts. The word 'journal,' as an example of a sign, has no materiality of its own, it is merely a symbol, a representation of an object that exists independent of language. Duras could, of course, refer to her personal diary as 'house,' 'paper,' or 'clafoutis' and understand perfectly her own intended meaning, but because these words are not typically assigned to written personal narratives and 'journal' is, 'journal' must be used to convey the intended meaning. The primary function of the sign is to recall an object that is absent from present perception; it comes into being at the same time as imagination and memory (Derrida, "Signature" 6). The signs that comprise language are therefore only approximations, lowest common denominators, of what they are meant to express. Moreover, any single sign "can be cited, put between quotation marks; in so doing it can break with every given context, engendering an infinity of new contexts in a manner which is absolutely illimitable" (12). Here Derrida is speaking specifically of the sign as it relates to writing - both, as we have seen, can extend beyond their original intended context and engender new meaning for a recipient who approaches what has been written with a different set of personal and historical frameworks. There can be no single context for a given utterance, and as such what is written can always be misconstrued. The words and sentences of written language, literary or otherwise, with their recourse to preestablished customs, can be read and heard by others, quoted and understood. In this way, they "belong" to other people - they are, in a manner of speaking, universal. (Blanchot, "Littérature" 298). 
This universally possessed language perpetuates a feeling of reassurance, giving objects their meaning and place in a world organized by language. But they also transform the being of this object into a mere abstraction: "[Le mot] est l'absence de cet être, son néant, ce qui demeure de lui lorsqu'il a perdu l'être, c'est à dire le seul fait qu'il n'est pas" (Blanchot, "Littérature" 312). When we consider this understanding of writing and language in relation to coming to terms with trauma, it once again becomes clear that conscious, intellectualized testimony will inevitably fail to capture the totality of a traumatic experience. We will recall that before its entrance into the controlled sphere of language, trauma designates the absence of knowledge/understanding of an event that is so incomprehensible that it resists language. During a traumatic event, the self ceases to understand its relationship to time and place, and without this understanding one cannot communicate the details or the significance of a traumatic experience. Speech without referent, without a signified object, cannot be transferred; we cannot do anything with an object lacking a name (312). When the traumatic experience is narratized, as it is in the original diary and then with more precision in the rewritten version, language's organizational influence divests the narrating Duras of the anguish and confusion of her trauma because narratization (what Derrida would call "saying the event") transforms its identity:

One of the characteristics of the event is that not only does it come about as something unforeseeable, not only does it disrupt the ordinary course of history, but it is also absolutely singular. On the contrary, the saying of the event or the saying of knowledge regarding the event lacks, in a certain manner a priori, the event's singularity simply because it comes after and it loses the singularity in generality. (Derrida, "Impossible Possibility" 446) 
In this light narrating and writing inevitably supplant and render familiar the event or idea that initially evades a pre-established language. As I explained in chapter two, contextualizing what begins as an only quasi-perceived event through narratization engenders understanding and acceptance. Like a trauma survivor trying to make sense of his or her fragmented memories through bearing witness, the author's intent for a text begins inside, and is only realized through its emergence into language. When we compare the rewritten "La douleur" to the original diary, Duras' development of a progressively more coherent and "literary" narrative reveals a firmer understanding and acceptance of both her traumatic past and her inability to ever know "the whole story." This notion of a more literary narrative has been frequently mentioned in the preceding chapters, but as this chapter pertains to the act of writing in particular I would like to expand further on this idea. Barthes' provides the following description of poetic (that is to say, literary) vocabulary: “ [It is] one of usage, not of invention: images in it are recognizable in a body; they do not exist in isolation; they are due to long custom, not to individual creation" (Barthes 45). This should call to mind Blanchot's definition of shared language described earlier in this chapter, as Blanchot identifies a similar presence of recognizable bodies and long custom that privilege shared understanding over individual and private language. Literature too is built on the loss of singularity: there is an underlying deceitfulness in language and writing that inevitably betrays the author's intent ("Littérature" 294). Writing is a perpetually-already failing act. It inscribes itself within "the vast History of Others" (Barthes 14) and transforms the author's intent into a 
more intellectualized, even stylized, narrative. While I have already devoted a great deal of attention to comparing and contrasting passages from the original diary and the rewritten version, I would like to do so (briefly) once again in order to illustrate how the language of the rewritten version modifies the ideas put forth in the original diary.

The general disorder of the initial narrative challenges the linearity that is built into language - it is as if the narrating Duras is trying to describe more than one imperceptible thought at a time. Her writing suggests that she is more concerned with transcribing her impressionistic thoughts as they occur than she is with communicating their true significance to an other:

C'est arrivé en une seconde. Qu'est-ce qui m'arrive ? La nuit noire est aux fenêtres qui me guette. Je tire les rideaux. Elle me guette toujours. Qu'estce qu'il m'arrive. Les signes, la chambre est pleine de signes noirs et blancs, noirs et blancs. Plus de battements aux tempes. Ce n'est plus ça. Je sens que ma figure change, change, se défait lentement. Il n'y a personne. (CG 219)

The breach in the conscious perception of time and self that is characteristic of trauma is evoked in this passage through the narrating Duras' lack of precision ("c cest arrivé," "les signes") and her general inability to describe what exactly is happening to her (“Qu'est-ce qui m'arrive ?”). These signs of which she speaks cannot be read, cannot be put into a comprehensible language. As the author of her own testimony, she is responsible for interpreting the signs' significance, but at this moment in time she is incapable of doing so. In this way, this excerpt is indicative of a private speech that obscures for others the true significance of this event and the feelings it inspires. Despite the fact that the constricted nature of language prevents the totality of the traumatic event 
from being fully formally recorded, even in this original diary, Duras' narrative style and tone convincingly articulate the impressionistic quality of thought before it is organized and rationalized. The rewritten and more literary version of the diary takes this fragmented language and builds upon it, echoing Blanchot's observation that literature is built on its own ruins (Blanchot, "Littérature" 294) :

C'était arrivé en une seconde. Plus de battements aux tempes. Ce n'est plus ça. Mon visage se défait, il change. Je me défais, je me déplie, je change. Il n'y a personne dans la chambre où je suis. (LD 49)

We should first note that in this version of the event, the excerpt begins not with the French passé composé, which expresses a completed action in the past, but with the plus-que-parfait, a tense denoting a past already in the past. Here Duras attempts to maintain the uncertainty of this episode by preserving some of its original vague and fragmentary quality, but she does so from a secure, historically informed vantage point. Furthermore, in this episode the sensory language of the first excerpt (“Je sens que ma figure change...se défait") is replaced by an intellectualized tone that incorporates the metaphorical language of literary custom (Je me défais, je me déplie). This sacrifice of what Philippe Gasparini calls "le « vrai » au «beau »" indicates that the author "[obéit] à des considérations esthétiques étrangères à son objet" (144), confirming that writing, and particularly literary writing, inevitably distances the author from his or her text. As I have already noted, many of the changes in tone made to the original diary curtail its specificity, as seen for example in the frequent replacement of the personal pronoun ' $\mathrm{je}$ ' with 'elle'. In the case of the current excerpt, however, the narrating Duras retains the pronoun 'je' and in fact uses it twice as much as in the first excerpt, an act which should, 
at least theoretically, allow her to limit the distance between her actual self and the events she describes. 'Je' fixes the narrating Duras' presence in the narrative and points to a reintegrated self who understands her relationship to her self and her surroundings ("mon visage se défait," “Je me défais," "il n'y a personne dans la chambre où je suis").

However, such signs in the text that point to the author (which also include temporal adverbs and conjugated verbs) create what Foucault refers to as an "alter ego whose distance from the author varies, often changing in the course of the work" (Foucault 112). 'Je,' like 'elle' is evocative of a certain distance between Duras and her textual self (though 'je' is arguably closer than 'elle'), both in the rimbaldian sense of 'je est un autre' or Gasparini's Est-il je? The text, whether written in the third or first person, is thus separated from its author through its very writing; its emergence into the realm of communication depends entirely on the systematized and self-canceling shared language discussed earlier in this chapter and explored in further detail in the work of poststructuralist writers such as Blanchot, by Foucault in "What Is an Author?" and by Barthes in "Writing Degree Zero."

Like the inherently incomplete testimony that results from witnessing trauma, writing (as both physical act and determination of form) is tethered to personal intention that erodes under the weight of the very language that allows it to become recognizable. This inability to fully control both trauma and a text can also, Blanchot tells us, be likened to an inability to consciously experience death:

Je ne puis dire à proprement parler que je meurs, puisque - mourant de mort violente ou non - je n'assiste qu'à une partie de l'événement. Et une grande partie de l'effroi que j'éprouve à l'idée de la mort tient peut-être à 
ceci: vertige de rester suspendu en plein milieu d'une crise dont ma disparition m'empêchera, au grand jamais, de connaître le dénouement. ("Regards" 245)

As Blanchot rightly observes, dying necessarily entails a lack of comprehension. Consciousness is "snuffed out" before it can record death in its entirety (Gregg 12). Like trauma and writing, death is characterized by its inability to ever be completely known. Though it is not the author's own death that is the focus of "La douleur," both versions of the narrative are devoted to the description and interpretation of a similar kind of vertigo of uncertainty. Duras' writing and rewriting of the original diary can therefore be viewed as the process and the place wherein recognition of the traumatic event is born (Laub 57) and control over traumatic memory is negotiated.

In this light, Duras' identity as author and trauma survivor is derived through her creation of the text, the narrative of trauma. Like a trauma survivor's testimony, which is only grasped through its creation, the emerging text exists only through its association with the author. Blanchot tells us: “[L'auteur] a besoin de l'œuvre qu'il produit pour avoir conscience d'eux et de lui-même. L'écrivain ne se trouve, ne se réalise que par son oeuvre; avant son oeuvre, non seulement il ignore qui il est, mais il n'est rien" ("Littérature" 296). Because the author's intent for a text begins as an internal, unnarratized absence (in the sense that this intention has no materiality until it is committed to written language), the author is the only person capable of externalizing this intention into language. The narrative contents of the text are therefore "ni bien ni mal écrit, ni important ni vain, ni mémorable ni digne d'oubli : c'est le mouvement parfait par lequel ce qui au-dedans n'était rien est venu dans la réalité monumentale du dehors comme 
quelque chose de nécessairement vrai, comme une traduction nécessairement fidèle" (Blanchot, "Littérature" 297). This rien of which Blanchot speaks refers to an author's initial intent for a text, but it may also be thought of as the imprint of a traumatic experience. Both begin beyond the confines of linear language and must be transposed into language before acquiring a materiality of their own. Although this language can only be an approximation of the author's intent, it is necessarily faithful by virtue of the fact that the author has given it his or her approval to effectively convey intention. As the interview between Duras and Mitterrand discussed in the previous chapter (56) illustrates, there can be no single definitive interpretation of any given event. Mitterrand remembers waiting with Duras in the stairwell of her apartment building the day of Robert's return; Duras does not even remember Mitterrand waiting with her. Duras' account of Robert's return (which, we will recall, is absent from the original diary) therefore embraces what has been forgotten and appears in the rewritten version not in the form of authoritative History, but as an intellectualized and ordered interpretation of Duras' own subjective experience.

Blanchot's observation that the text is a faithful representation of its author indirectly invokes the possibility for emotional accuracy in intellectualized writing. Because emotional accuracy is derived through intellectualization, and intellectual memory cannot exist without deep memory behind it, the sentiments expressed in an intellectualized version of events are tacitly emotionally accurate. The raw emotion that intellectual memory seeks to encapsulate is rooted in the narrator's personal subjective experience. Rewriting the original diary with attention to intellectualized emotional 
accuracy instead of purely impressionistic description does not trivialize the raw emotion within. Instead, through its transformation into a literary object, the original diary's disorganized narrative becomes a transmittable testimony through its recourse to intellectualized language that is substantiated by historical fact and poetic language. But, as we have seen, what allows the individual elements comprising the narrative to be transferred also paradoxically allows them to be misconstrued and judged through the lens of divergent personal and historical frames of reference. The interest that a reader takes in the narrative is different from the author's interest that made it a pure expression of the self. Different interest changes the work, transforms it into something different, something in which the author can no longer recognize the "perfection première" (Blanchot, "Littérature" 298).

It is here that the format of "La douleur" begins to play an integral role. As a written object the diary also assumes an addressee and the content transcribed within is able to extend past the presence of the diarist. The events described in a diary are therefore equally susceptible to the erasure that is built into language. However, the diary also possesses certain formal traits that allow it to symbolically counteract the generalizing influence of language and literary custom. By embedding her account of her traumatic past in a diary, Duras suspends the possibility of an addressee other than herself and with it the possibility for misreading and recontextualization. Lynn Z. Bloom provides the following definition of truly private diaries:

[T]hose bare-bones works written primarily to keep records of receipts and expenditures, the weather, visits to and from neighbors, or public occurrences of both the institutional or sensational sort. Written with 
neither art nor artifice, they are so terse they seem coded; no reader outside the author's immediate society or household could understand them without extra-textual information. (Bloom 25)

While Duras' original war-time diary is not so coded that it is impenetrable, it does typify the kind of private record keeping that Bloom describes:

Mercredi 25. Rien.

Jeudi 26. Rien. D. a appelé le docteur. J'ai de la fièvre, ce n'est pas grave. Une grippe, dit le docteur. Il m'a donné un calmant. Mme Cats et D. sont assis auprès de moi. Il fait nuit. C'est dix heures du soir. Riby a téléphoné. Je ne le connaissais pas. Il a demandé Robert. Il était dans la colonne, il s'est évadé après Perrotti, il est rentré avant lui.

Vendredi 27. Rien dans la nuit. D. m'apporte Combat. Première séance à San Francisco: «Molotov impassible, Bidault soucieux, Eden rêveur... On y parla beaucoup de justice, à la grande satisfaction des petites puissances. » En dernière minute, les Russes ont pris une station de métro. Stettin et Brno sont pris" (CG 226)

The original diary gives to the reader the image of an event, simultaneously evoking its individuality and subjectivity. We are not told who Riby is or Duras' relationship to him. We are not given any outside context for what she reads in the newspaper. This diary quietly suggests that its contents have nothing to do with literary custom or a wider readership. In her preface to "Monsieur X., dit ici Pierre Rabier," the second narrative in the collection of stories in La Douleur, Duras states, "ça ne s'agrandissait jamais, ça n'allait jamais vers le large de la littérature" ( $L D 90)$. Duras seemed to be of the same opinion regarding "La douleur," and indeed confided as much to Marianne Alphant when asked about the collection's belated publication: “J'ai dû penser longtemps que c'était l'histoire du retour de quelqu'un. Qu'on avait dû publier ça déjà beaucoup. Que ce n'était pas la peine d'ajouter un récit de plus" (Alphant 37). It appears that by presenting "La douleur" as her original diary, Duras hoped to prevent it from becoming just another 
"story of a return" - it is her account of Robert's return. This rewritten narrative endeavors to resist the transformative influence exacted by the wider body of literature in which authors become detached from their work - by maintaining its identity as a diary. In this way, "La douleur" bears Duras' personal signature throughout.

Unlike other narrative forms in which the actual writing is secondary to the story that it tells, diaries expose what is ordinarily an unnoticed reflexive action and give the process of writing a "role in the plot" (Abbott 9). The diary does not present its reader with a wholly determined narrative: its contents are fragmented; they do not formally anticipate a sense of closure: "le diariste se contente de noter ses impressions au jour le jour sans souci d'ordonner, de convaincre, de justifier ni de conclure" (Gasparini 217). Instead, the diary shows the author planning a work (17) and in doing so purports to give truth to real, not invented, consciousness (18). The diary professes to capture the intent of its author while avoiding the artificiality of literary writing: "Là-bas, dans l'espace de l'œuvre [littéraire], tout se perd. Le journal est l'ancre qui racle contre le fond du quotidien et s'accroche aux aspérités de la vanité" (Blanchot, "Livre" 227).

One of the reasons the diary is able to safeguard its author and contents from the dangers of writing is its recourse to the real calendar of the author:

Ecrire son journal intime, c'est se mettre momentanément sous la protection des jours communs, mettre l'écriture sous cette protection, et c'est aussi se protéger de l'écriture en la soumettant à cette régularité heureuse qu'on s'engage à ne pas menacer. Ce qui s'écrit s'enracine alors, bon gré mal gré, dans le quotidien et dans la perspective que le quotidien délimite. (224) 
What is recorded in a diary is thus anchored to the "actual" world outside the text and to the diarist. It is written in a present-present, unsubstantiated by future insight.

Furthermore, by assuming the self as its sole addressee, the diary encourages the reader to let go of the perspective of the Other (Abbott 24). The lack of elaborate contextual clues mimics private speech and reminds the reader (that is to say, a reader other than the diarist herself) that what is written on the page is not consciously intended for a wider audience. We read what Duras describes herself seeing, thinking, and feeling because in this framework, the author and addressee are one: "Métaphoriquement, l'écrivain injecterait sa pensée directement dans les veines du lecteur. De cette relation fusionnelle est proscrite toute préoccupation littéraire qui ferait obstacle à la communication immédiate de l'émetteur au récepteur" (Gasparini 167).

Using the diary format as a framework for chronicling trauma, Duras is seemingly protected against the inevitable disappearance from the text that the author undergoes. Her narrating self is firmly rooted in time and space, affirming the sincerity of the events she recounts and further reinforcing their emotional accuracy. However, this protection and privacy is once again called into question in the rewritten version, as this reformulation of events blurs the line between private and public document. By maintaining the original diary format, Duras invokes the same protective calendar and the same singular addressee, along with the feeling of intimacy that the latter affords. Yet two salient features of this rewritten version disrupt the security of this otherwise closed space. The first is the progressively more prominent presence of intellectualized memory, which gives rise to a style of writing that is much more literary and thus supersedes the 
"lack of art and artifice" that is characteristic of truly private diaries. Secondly, we cannot ignore the fact that Duras expressly intended for "La douleur" to be published and available to a wider audience. Though still addressed to the self, "La douleur" simultaneously accepts the possibility of a wider readership. It is the shared testimony that can be appropriated by others.

What to make of a rewritten journal that can no longer be classified as a purely private document, but resists categorization as fiction, even if that fiction is in the form of an autobiographical novel? If, as Gasparini asserts, the illocutionary functions of fiction and autobiography are in direct opposition to each other (13), how might we classify a text such as "La douleur," which is neither entirely fictionalized nor completely historically verifiable? As I have argued throughout the present study, the original diary and "La douleur" do not attempt to objectively describe the historical events of the spring of 1945; rather they capture, recount, and refine the experience of coming to terms with trauma. We know from the previous discussion of trauma's origins and the poststructuralist conception of writing that an absolute Truth is unattainable. We cannot know the entirety of a traumatic event nor can we fully understand the singular impression that a trauma survivor essays to convey through language. However, what we can observe is the trauma survivor's progression toward a unified and coherent narrative, which in turn gives us a clearer sense of the emotion involved in processing trauma. I would therefore like to propose that the valorization of emotional accuracy in "La douleur" allows it to be classified not as invented fiction, not as verifiable autobiography, 
but as autofiction, a genre which embraces the gaps in the understanding of the self and the event and places emphasis not on the vrai but on the vraisemblance.

The term 'autofiction' was conceived of by author and critic Serge Doubrovsky and first appeared as a prière d'insérer on the back cover of his 1977 novel Fils: “Autobiographie? Non. [...] Fiction d'événements et de faits strictement réels ; si l'on veut, autofiction, d'avoir confié le langage d'une aventure à l'aventure du langage, hors sagesse et hors syntaxe du roman, traditionnel ou nouveau" (qtd. in Gasparini 22). Works considered as belonging to this genre are characterized by three particular traits. First, they are works of literary writing; meaning that they allegorically represent what could take place $(9,12)$. Second, the author, narrator, and main character profess to be the same individual (12). Lastly, tying together these two disparate qualities is the importance that is accorded to the presence and influence of psychoanalysis on and within the narrative (12). These three criteria are inarguably present in "La douleur": the narrative style and tone are intellectualized, influenced by history and literary custom; Duras is at once author, narrator and central figure (despite her sporadic dissociative use of the pseudonym 'Madame L.' and the pronoun 'elle'); and the ebb and flow of deep memory and intellectual memory demonstrate her ongoing attempt to assign psychic significance to an incomprehensible event.

What further distinguishes autofiction from fictional novels, autobiography, or even autobiographical novels is the degree of verisimilitude and verifiable historical events recounted in the narrative. In Est-Il Je?, Gasparini draws a clear distinction between these four genres. While the characteristics of fiction and autobiography should 
be rather clear, the difference between autofiction and the autobiographical novel is less so. An autobiographical novel such as Charles Dickens' David Copperfield or Duras' Un Barrage Contre le Pacifique recounts events that are not wholly historically identifiable but seem natural or verisimilar. The characters could be real, could be an alias for the author, and the events they describe may very well have occurred. The events in a work of autofiction, on the other hand, are neither wholly historically identifiable nor entirely plausible (30). In other words, in a work of autofiction the reader may perceive the events recounted as being incompatible with information that he or she already possesses (25). For example, when the narrating Duras suddenly inserts comments such as "Je le saurai demain par les journaux" ( $L D$ 32) or "Sa fille était morte en mars 1945, on lui a notifié la mort en novembre 1945" ( $L D$ 58) in an entry supposedly written in April, it is difficult to believe that the narrative we are reading is truly an authentic diary written just after the Liberation. But this "hesitation," as Gasparini calls it, on this issue of verifiability and verisimilitude that defines autofiction does not necessarily imply that autofiction is merely a sophisticated term to describe a work of fiction parading as autobiography or memoir. In fact, 'hesitation' is reminiscent of the inevitable inability to recall a traumatic event in its entirety or capture its total significance in language. It signals a particular valorization of the fallibility of both memory and language. In other words, autofiction may be thought of as the narrative of personal analysis and interrogation, a point which Doubrovsky confirms in his essay "Autobiographie / vérité / psychanalyse": “L'autofiction, c'est la fiction que j'ai décidé en tant qu'écrivain, de me donner à moimême et par moi-même, en y incorporant, au sens plein du terme, l'expérience de 
l'analyse, non point seulement dans la thématique, mais dans la production du texte" (qtd. in Gasparini 23).

Because the experience of the analysis itself is of central importance in a work of autofiction, it becomes a fitting genre in which to inscribe a work like "La douleur" as well as the original diary on which it is based. These two narratives both search in their own way to describe, contextualize, and reconcile an absence of comprehension, and in this way they attest to the challenge faced by the narrating Duras to "say" the event without detracting from her singular experience of it. Neither version can perfectly convey the qualia of her sensory impressions from a traumatic period. Together, however, they complete each other and link the initial fragmented memory to a more coherent translation of the same thought. In this way we are able to chart the progression from overwhelming uncertainty of an event without closure to understanding and acceptance. As a work of autofiction styled after a diary, "La douleur" (and the original version of the narrative) are able to balance the erasure of the subject that inevitably occurs in writing not only by making apparent this disappearance of referentiality, but by confirming that it is an integral part of coming to terms with trauma. 


\section{Conclusion}

"La douleur" - both the original diary and the rewritten version - is a work characterized by duality. In both versions we see two modes of remembering (deep memory and intellectual memory), two modes of narrating (from the present of 1945 and the present of the rewritten version), and two modes of writing (one that gives and one that takes away). It is in this space that Duras, as both narrator and author, survivor of trauma and witness, comes to know what was once beyond the grasp of her own consciousness. What was previously beyond the realm of the narrating Duras' conscious perception is solidified and affirmed in the rewritten narrative: her husband disappeared, may have been dead, but ultimately lived, and, at the same time, she too endured this crisis of not knowing.

The discourse that has previously surrounded "La douleur" has primarily focused on its veracity as a historical document. In the present study I have argued that such attempts to compare "La douleur" to the historical record are misguided, as doing so detracts from what "La douleur" truly struggles to convey. "La douleur" is not, as some have implied, a purposeful betrayal of the historical record that serves only to bolster Duras' authorial mythos. If indeed historical accuracy were truly the goal of either version of "La douleur," I believe much of the emotion described within would have been left out. Instead, what we are presented with in both versions of "La douleur" is a narrating Duras who seeks closure to a traumatic past through bearing witness to the events and emotions experienced during this period. Yet such genuine witnessing is 
implicitly impossible, as the mechanisms of trauma and writing inevitably impede such recognition. In both versions of the narrative the traumatic disappearance of Duras' husband persists in an ongoing present; the narrating Duras rambles, repeats herself, and describes her surroundings in fragmented terms, all of which prevent the full significance of what she is describing from becoming wholly transferable. In the original diary we see a narrating Duras who still does not know what to make of Robert's prolonged absence. Conversely, when these events are revisited and rewritten the narrating Duras is no longer unified with the narrator in the original diary, despite her best efforts to mask their divergence. The narrating Duras in the rewritten "La douleur" has had 40 years to reflect upon and intellectualize this experience, 40 years of History in which to contextualize her feelings, and 40 years of reassurance that Robert did not die in a concentration camp. These 40 years of insight may erase the chaotic quality of the original diary, but in so doing they replace this chaos with a more precise description of the original diary's emotion.

Even if Duras had intended to present a purely factual account of her experience during and after the war, the very nature of memory and writing the self would have made this endeavor impossible. "La douleur" is as much a meditation on the psychological effects of grief as it is on the act of writing and bearing witness. Though neither the original diary nor the rewritten version published in 1985 are completely and objectively faithful to the events in question, and never could be, each version reveals a narrating Duras that approaches the text from two distinctly different temporal positions. These differing narrative voices each reveal in their own way the many facets of a 
reintegrated self who has witnessed, evaluated, and rewitnessed a traumatic past. While some critics have seen this process as an indication of Duras' varying degrees of honesty, this does not constitute sufficient reason for dismissing the contents of "La douleur" as fiction. The truth, as we have seen, is unattainable. The constraints of linearity and iterability imposed by language prevent such truth, traumatic or otherwise, from ever being fully realized. And yet, to demand such unwavering veracity from a text would be beside the point, because to do so would require that we, as readers, possess the exact same set of referents as the author whose text we are reading. This too is a complete impossibility due to the innately subjective nature of human experience. What is communicated, whether it be spoken or written, can only ever be an approximation of its author's intent, and the two versions of "La douleur" attest to this both independently and jointly. Though they focus on the same events, their individual methods of articulation are drastically different, confirming the ebb and flow of intellectual and deep memory when endeavoring to re-externalize and re-integrate trauma.

I therefore believe that we may say with certainty that the story being retold in "La douleur" is not meant to chronicle the quotidian, or even the extraordinary, of a liberated Paris in April 1945; rather its purpose is to describe the emotional turmoil Duras experienced during her wait for Robert, and this is accomplished, above all else, through the existence of two versions of the same diary. Duras' account of the quotidian is therefore not in service of the historical record. The events described by her narrating-self are not the focus of the story, but a backdrop for her description of her psychological 
state. Following this logic, when reading "La douleur" critical attention should shift from the veracity of the event being described to how this event is interpreted and articulated.

\section{Works Cited}

Abbott, H. Porter. Diary Fiction: Writing as Action. Ithaca: Cornell University Press, 1984.

Adler, Laura. Duras: A Life. Chicago: University of Chicago Press, 2000.

Alphant, Marianne. “Avril 45: Nuit et Duras.” Libération 17 April 1945: 37.

Barthes, Roland. "Writing Degree Zero.” Writing Degree Zero and Elements of Semiology. Trans. Annette Lavers and Colin Smith. Boston: Beacon Press, 1967. 9-88.

Blanchot, Maurice. "Le Journal Intime et le Récit” Le livre à venir. Paris: Gallimard, 1959. 224-230.

---. “La Recherche du Point Zéro.” Le livre à venir. Paris: Gallimard, 1959. 246-255.

---. "La Littérature et le droit à la mort." La Part du feu. Paris: Gallimard, 1949. 291-331.

---. “Regards d'outre-tombe.” La Part du feu. Paris: Gallimard, 1949. 238-248.

Bloom, Lynn Z. “'I Write for Myself and Strangers: Private Diaries as Public Documents." Inscribing the Daily: Critical Essays on Women's Diaries. Ed. Suzanne L. Bunker and Cynthia A. Huff. Amherst: University of Massachusetts Press, 1996. 23-37.

Burrin, Philippe. "Vichy." Les lieux de mémoire. Ed. Pierre Nora. Vol. 3. Paris: Gallimard, 1984. $321-345$. 
Caruth, Cathy. Unclaimed Experience. Baltimore: The Johns Hopkins University Press, 1996.

Derrida, Jacques. "A Certain Impossible Possibility of Saying the Event.” Trans. Gila Walker. Critical Inquiry 33.2 (2007) : 441 - 461. Web. 18 Feb. 2013.

---. "Signature Event Context." Limited Inc. Trans. Jeffrey Mehlman and Samuel Weber.

Evanston: Northwestern University Press, 1988. 1-21.

---. "Différance." Margins of Philosophy. Trans. Alan Bass. Chicago: University of Chicago Press, 1982. 1-27.

Duras, Marguerite. Écrire. Paris: Gallimard, 1993.

---. Hiroshima Mon Amour. Paris: Gallimard, 1960.

---. La Douleur. Paris: P.O.L, 1985.

Duras, Marguerite, Sophie Bogaert, and Olivier Corpet. Cahiers De La Guerre Et Autres Textes. Paris: P.O.L/Imec, 2006.

Duras, Marguerite, and François Mitterrand. Le bureau de poste de la rue Dupin. Paris: Gallimard, 2006.

Felman, Shoshana, and Dori Laub. Testimony: Crises of Witnessing in Literature, Psychoanalysis, and History. New York: Routledge, 1991.

Foucault, Michel. "What Is an Author?" The Foucault Reader. Ed. Paul Rabinow. New York: Pantheon Books, 1984. 101-120.

Freud, Sigmund. The Interpretation of Dreams. Trans. Joyce Crick. Oxford: Oxford University Press, 1999.

---. Beyond the Pleasure Principle. Trans. James Strachey. New York: Liveright, 1950. 
Gasparini, Philippe. Est-il je? Paris: Seuil, 2004.

Genette, Gérard. Narrative Discourse: An Essay in Method. Trans. Jane E. Lewis and Jonathan Culler. Ithaca: Cornell University Press, 1972.

Gregg, John. "Blanchot's Suicidal Artist: Writing and the (Im)Possibility of Death." Maurice Blanchot and the Literature of Transgression. Princeton: Princeton University Press, 1994. 35-45.

Hill, Leslie. Marguerite Duras: Apocalyptic Desires. London: Routledge, 1993.

Jacobs, Gabriel. "Spectres of Remorse: Duras's War-Time Autobiography." Romance Studies. (1997): 47-58

Janet, Pierre. Psychological Healing: A Historical and Clinical Study. Trans. Eden and Cedar Paul. Vol. 1. London: George Allen \& Unwin Ltd, 1925.

Jones, Colin. The Cambridge Illustrated History of France. Cambridge: Cambridge University Press, 1994.

Koreman, Megan. “A Hero's Homecoming: The Return of the Deportees to France, 1945." Journal of Contemporary History 32.1 (1997) : 9 -22. Web. 20 Feb. 2013.

Lacan, Jacques. The Four Fundamental Concepts of Psycho-Analysis. Trans. Alan Sheridan. Ed. Jacques-Alain Miller. New York: Norton, 1978.

Langer, Lawrence L. Holocaust Testimonies: The Ruins of Memory. New Haven: Yale University Press, 1991.

Rousso, Henry. Le syndrome de Vichy. Paris: Seuil, 1987.

Willging, Jennifer. “'Truth' in Memory and Narrative: Marguerite Duras's 'Monsieur X. dit ici Pierre Rabier'." Telling Anxiety: Anxious Narration in the Work of 
Marguerite Duras, Annie Ernaux, Nathalie Sarraute, and Anne Hébert. Toronto:

University of Toronto Press, 2007. 27-72 